\title{
Structure of the Gabon Margin from integrated seismic reflection and gravity data
}

\author{
Stéphanie Dupré ${ }^{\mathrm{a},{ }^{*}}$, Sierd Cloetingh $^{\mathrm{a}}$ and Giovanni Bertotti ${ }^{\mathrm{a}}$ \\ a Tectonics and Structural Geology Department, Faculty of Earth and Life Sciences, Vrije Universiteit, de \\ Boelelaan 1085, 1081 HV Amsterdam, The Netherlands \\ *: Corresponding author : Stéphanie Dupré, tel.: +33 (0)2 982247 09, fax: +33 (0)2 98224509 , \\ email address : stephanie.dupre@ifremer.fr
}

\begin{abstract}
:
In the South Gabon Basin, deep multi-channel seismic reflection and gravity modeling analysis have shed light on key features of the structure of the margin. The thinned continental crust beneath the Gabon Margin appears to be composed of two distinct layers, separated by a clear, strong and more or less continuous reflector running in the 7-10 s TWT window. The lower crust is characterized by a higher density, intermediate between the lower values of the upper crust and the denser values of the mantle. The lower crust is irregularly shaped and presents lateral thickness variations along the direction of thinning and along the coast. In the offshore thinned continental domain, the lower and upper crust form a $20-25 \mathrm{~km}$ thick body. Crustal thicknesses point to a relatively sharp and narrow transition, along a few tens of kilometers, between the unthinned and the thinned continental crust. The high density layer identified offshore Gabon presents similar characteristics in density, geometry and spatial distribution, as the underplated magmatic bodies observed along volcanic margins, e.g. along the South Atlantic Namibia Margin or the North Atlantic Vøring Margin. Although this lower crustal body could possibly represent ultra mafic serpentinized rocks or high grade metamorphic crustal rocks, we suggest that it could be composed of mafic rocks. Magmas resulting from partial melting during rifting may underplate the crust and/or be intruded in the lower crust through a system of dykes and sills. In this view, the present-day crustal thicknesses along rifted margins, characterized by magmatic underplating and/or intrusion, are not representative of the thinning that the crust experienced during rifting. Results of this study point to relatively shallow sedimentary basins along the South Gabon Margin. The deepest offshore depocenters located under the westernmost side of the continental platform appear to be associated with the deepest syn-rift basins These basins seem to extend along 20 to $40 \mathrm{~km}$ in the $\sim \mathrm{NE}-\mathrm{SW}$ direction with a present-day average thickness of $7.3 \mathrm{~km}$. Offshore Gabon, whereas the crustal thinning appears significant, the syn-rift deposit are not thick. We suggest that the area was anomalously uplifted during the rifting phase, due to an elevated thermal lithospheric gradient. The conclusions derived from our seismic and gravity analysis are consistent with the implications such a thermal anomaly would have on the tectonic evolution of a rifted margin with 1) an underplated high density lower crustal layer, 2) shallow depth syn-rift basins associated with a relatively thin crust and subsequently 3 ) elevated recorded subsidence rates in the initial post-rift stages.
\end{abstract}

\section{Research Highlights}

The Gabon Margin appears characterized by an underplated high density lower crustal layer. Shallow depth syn-rift basins are associated with a relatively thin crust. Seismic and gravity analysis points to an anomalous uplift of the Gabon Margin during the rifting phase. Crustal structure, syn-rift infill and post-rift subsidence are consistent an uplift of the Gabon Margin during the rifting phase. The uplift of the Gabon Margin is possibly due to an elevated thermal lithospheric gradient.

Keywords : Deep seismic; Gravity modeling; Crustal structure; Rifted continental margins; Lower crust; Gabon Margin 


\section{Introduction}

Over the last decades, scientific interest in West Africa has risen due to discoveries of large petroleum provinces, largely in deep water parts of continent-margin basins. Joint efforts from Industry and Academy have led to a better accessibility to the data and to an increase of scientific publications and knowledge. However, the offshore sedimentary basins of the tropical domain (Angola, Gabon, Brazil) are characterized by massive evaporite deposits that considerably perturb the seismic, the most powerful tool to image sedimentary and crustal structures in deep marine environments. Despite a good reflection seismic image of the post-salt sedimentary sequence (Dupré et al., 2007), characteristics of the pre-salt sequence, which mainly includes the syn-rift sequence and the basement, are poorly known and are subject to large interpretational uncertainties. As a direct consequence, fundamental questions regarding rifting kinematics and controlling processes require further investigation. The purpose of this study is to determine the deep geometry of the margin with special attention to depth of the sedimentary basins and to lateral variation in crustal thickness. Offshore Gabon, 2D deep reflection seismic and well data provided by Western Geco and Norsk Hydro have been analyzed together with satellite gravity data from Sandwell \& Smith (1997). Gravity modeling was conducted to constrain the structure of the Gabon Margin. The new picture of the margin's structure highlights key aspects of rifting processes and related margin's formation.

\section{Geological setting}

In Late Jurassic time ( 150-140 Ma), continental rifting began between South America and Africa and led to the opening of the South Atlantic and to the formation of the West and Central Africa Rift System (Binks \& Fairhead, 1992; Davison, 1999; Kampunzu \& Popoff, 1991; Nürnberg \& Müller, 1991; Teisserenc \& Villemin, 1990). Crustal separation and onset of oceanic spreading took place $\sim 133 \mathrm{Myr}$ ago (magnetic anomaly M11) in the Cape Basin of South Africa and propagated northward to the Gulf of Guinea (Binks \& Fairhead, 1992; Davison, 1999; Kampunzu \& Popoff, 1991; Nürnberg \& Müller, 1991; Teisserenc \& Villemin, 1990; Uchupi \& Emery, 1991). Three successive domains (austral, tropical and equatorial), delimited by inherited Gondwanian mega-discontinuities, characterize the South Atlantic (Popoff, 1988). Complete separation between the South American and African continents occurred in Late Albian-Cenomanian times with the opening of the Equatorial Atlantic Ocean. Rifting opened Africa's new margins to marine sedimentation, initially in narrow epicontinental seas, later in deep ocean basins (Fig. 1). Major basins around Africa were filled with great thicknesses of Cretaceous and Cenozoic marine sediments.

The Gabon Basin is located at the limit of two old cratons which have been stable since $\sim 2 \mathrm{Ga}$, the Sao Francisco Craton in Brazil and the Congo Craton in Africa (Castro, 1987; Reyre, 1984). In this region, two main rift axes developed, the GabonSergipe-Alagoas (GSA) trend and the Recôncavo-Tucano-Jatobá (TTJ) trend. While the RTJ trend evolved as a failed rift arm, the GSA trend indicated a transitional evolution between the rift and drift stage (de Matos, 1992). Along the Gabon Margin, onset of rifting started in Neocomian-Berriasian times, $\sim 144 \mathrm{Ma}$, based on dating of the oldest rift sediments corresponding most exclusively to fluviatile basal sandstones (Guiraud \& Maurin, 1991; Reyre, 1984; Teisserenc \& Villemin, 1990). In Cabinda (Fig. 2), a volcanic layer found on top of the pre-rift sequence has been dated at $140 \mathrm{Ma} \pm 5 \mathrm{Myr}$, corresponding to the Jurassic-Cretaceous boundary (Brice et al., 1982). The end of rifting has been dated and associated with the magnetic 
anomaly M0 at $\sim 118.5 \mathrm{Ma}$ (Guiraud \& Maurin, 1991; Teisserenc \& Villemin, 1990). Based on these ages, rifting duration can be approximated to $25 \mathrm{Myr}$.

The west African rifted margin is divided into two main domains by the oceanic Walvis Ridge (Fig. 1). South of the ridge, a volcanic margin extends from South Africa to Namibia (i.e. Walvis, Ludentz, Orange and Le Cap basins), and is characterized by seaward dipping reflectors (Gladczenko et al., 1997). The region north of the Walvis Ridge stretching from Angola to Cameroon is characterized by post-rift evaporites forming the South Atlantic Salt Basin (Mocamedes, Kwanza, Lower Congo, North and South Gabon, and Douala basins). The deposition of these sediments over such a large area, $250 \mathrm{~km}$ wide and $2000 \mathrm{~km}$ along strike (Jackson et al., 2000), was made possible by favorable climatic conditions and by restriction of the water circulation imposed by the Walvis Ridge (Dingle, 1999). The Gabon Margin is segmented by major normal faults parallel to the present-day coastline and by NESW trending strike-slip faults defining zones with partly different tectonic and stratigraphic histories (Teisserenc \& Villemin, 1990). The N'Komi fracture zone divides the Atlantic Basin into the North Sub-Basin and the South Sub-Basin (Fig. 2). North of Gabon, approaching the Equatorial domain, the west African margin acquires a more transform character (Mascle \& Blarez, 1987; Meyers et al., 1996).

The Phanerozoic evolution of the African plate has been characterized by diachronous uplift and/or rifting and magmatism since the Cambrian, and accompanying fragmentation of Gondwanaland from Carboniferous time to present (Kampunzu \& Popoff, 1991). The oldest pre-rift sediments along the Gabon Margin are found in the north, in the Interior Basin, which is separated from the offshore Atlantic Basin by the Lambaréné Horst (Fig. 2). According to Teisserenc \& Villemin (1990), they consist of Late Carboniferous to Triassic-Jurassic fluviatile and lacustrine deposits. Mbina Mounguengui et al. (2002) attributed the oldest sediments to be of Precambrian age. Continental rifting began in Berriasian time $\sim 144 \mathrm{Ma}$ (Reyre, 1984; Teisserenc \& Villemin, 1990) and led to the formation of extensional faults and, therefore, to series of grabens and horsts. The grabens were filled with fluvio-lacustrine sediments. Break-up occurred around 118 Myr ago. Following the cessation of rifting, in Late Aptian time, transitional to shallow marine sediments were deposited over most of the margin. They consist of sandstones, shales and evaporites (Ezanga sequence). From Late Aptian to Holocene time, the post-rift deposits consist of marine sediments, associated since Late Tertiary with the establishment of the Congo delta (Reyre, 1984).

During crustal extension (direction of N030 after Guiraud \& Maurin, 1991), normal faults subparallel to the present-day coastline were formed. Some of these major fault zones have been identified along the Gabon Basin by onshore outcrops, reflection seismic, well data and gravity anomalies (Brink, 1974; Karner et al., 1997). For instance, the Eastern Hinge separates continental margin sediments from the Precambrian Basement, while the Atlantic Hinge Zone is located in the shelf break area (Fig. 2). Based on wells (Brink, 1974; Teisserenc \& Villemin, 1990) and detailed biostratigraphy (Enoksen \& Lønøy, private communication, 2000), the Atlantic Hinge Zone controlled the separation between deeper marine environments in the west from shelf deposits in the east, e.g. Madiela, Cap Lopez and Azilé groups. 


\section{Database and methods}

\subsection{D deep reflection seismic}

The study is based on deep marine multi-channel seismic reflection lines acquired in the Gulf of Guinea in 1989 during the Probe (Proto-Rifts and Ocean Basin Evolution) survey, a project resulting from the collaboration between Industry and Academia. The first published results, mainly seismic interpretation in TWT can be found in Rosendahl et al. (1991) for the southern part of Gabon and in Meyers \& Rosendahl (1991) for the northern part. Further investigations, based on reprocessing of seismic lines, migration (Rosendahl et al., 1992) and post-stack reprocessing (Rosendahl \& Groschel, 1999; Rosendahl \& Groschel, 2000) led to a better understanding of the crustal structure. The present study incorporates 1) the depth conversion and 2) the gravity analysis and modeling of selected seismic lines. These are good quality seismic lines running in N-NE to S-SW direction, from the coastal area towards the ocean in the ultra-deep area $(3000<$ waterdepths $<4000 \mathrm{~m})$. They are numbered 1 , 2 and 3 from south to north (Fig. 2), and extend over 243, 280 and $346 \mathrm{~km}$, respectively (Fig. 2). They are displayed down to $16 \mathrm{~s}$ TWT (Figs 3, 4 and 5) and were provided to us in migrated version (Norsk Hydro, WesternGeco).

The depth conversion concerns the main seismic reflectors that delimit the different layers in the sedimentary section and the crustal units (Fig. 6). Several depth conversions associated with different velocity fields have been tested: constant velocity per seismic unit, linear velocity increase with depth for the post and pre-salt packages associated with different rates of velocity change with depth ( $\mathrm{k}$ parameter in Eq. 1), and lateral increase of crustal velocities. Two wells located along lines 1 and 2 (Fig. 2) constrain the calibration of the depth conversion. Velocity field adopted for each lithologic unit is indicated in Fig. 6. Interval velocities in sedimentary formations are derived from well velocity surveys (e.g. sonic logs) and stacking velocity functions (Stiteler, private communication, 2000). These velocity studies cover the offshore South Gabon (the proximal domain and the ultra-deep water area) and the offshore Angola (from the Lower Congo Basin in the north to the Kwanza/Benguela/Namibe basins in the south). Velocities have been determined down into the syn-rift section and have been calibrated to available well control. With the exception of the salt, the interval velocity of each lithology increases with depth, attributed to the compaction and is defined as following:

$$
\mathrm{V}(\mathrm{z})=\mathrm{V}_{\mathrm{o}}+\mathrm{kz}
$$

$\mathrm{V}(\mathrm{z})$ interval velocity $\left(\mathrm{m} \cdot \mathrm{s}^{-1}\right)$

$V_{o}$ initial velocity $\left(\mathrm{m} . \mathrm{s}^{-1}\right)$

$\mathrm{k}$ rate of ch ange in velocity with increasing depth $\left(\mathrm{s}^{-1}\right)$

$$
\mathrm{V}(\mathrm{t})=\mathrm{V}_{\mathrm{o}} \cdot \mathrm{e}^{\mathrm{kt}}
$$

t one way travel time (s)

$$
\mathrm{Z}=\mathrm{V}_{\mathrm{o}}\left(\mathrm{e}^{\mathrm{kt}}-1\right) / \mathrm{k}
$$

$$
\mathrm{Z} \text { depth (m) }
$$

Crustal velocity studies based on compressional wave velocities in rifted margins (e.g. the Vøring Basin, Raum, private communication, 2000) help us to define the velocity field along the Gabon Margin. Velocities increase laterally towards the ocean 
along a distance of $\sim 200 \mathrm{~km}$, from $6400 \mathrm{~m} / \mathrm{s}$ for a pure continental crust to 6900 $7000 \mathrm{~m} / \mathrm{s}$ for transitional crusts, and to $7200 \mathrm{~m} / \mathrm{s}$ for a pure oceanic crust.

Estimates of thinning, expressed by the thinning factor $1 / \beta$, have been derived from the crustal thickness. Surface wave velocity studies in the Congo and South Africa cratons suggest a crustal thickness of 36 and $34 \mathrm{~km}$, respectively (Hadiouche \& Jobert, 1988). In Angola, continental crustal thickness has been derived from deep reflection and refraction seismic data (Fig. 2), and can be estimated at least at $\sim 30$ $\mathrm{km}$ (Contrucci et al., 2004; Moulin, 2003). Based on these crustal thickness values and the fact that the Gabon Margin experienced one major rifting phase only, we consider a minimum value of the crustal thickness prior to rifting in the Gabon region of $30 \mathrm{~km}$.

\subsection{Potential-field data: gravity}

Marine gravity anomalies from Geosat and ERS 1 satellite altimetry (Sandwell \& Smith, 1997) have been compared with shipboard gravity data recorded during the Probe survey. Due to data permission and the fact that differences between the two signals are small (maximum a few mGal), free air anomalies (FAA) derived from geoid height measurements have been used (Fig. 2). The gravity signal is fairly similar between the three lines with an amplitude of $\sim 100 \mathrm{mGal}$ from the coastal area to the ultra-deep area (waterdepths of $\sim 4.0 \mathrm{~km}$ ) (Figs 2, 7 to 10). The strongest anomaly is localized along the continental shelf. Farther to the ocean (to the SW direction), the anomaly amplitude decreases with an inflexion point below the shelf break. The lowest values are located in the deep water area (waterdepths of 2.5-3.5 $\mathrm{km}$ ). The South Gabon Basin (Fig. 7b and c) is however characterized by a second high peak observed in the ultra-deep water area, at the southwest limit of the sections, possibly related to the presence of voluminous magmatic material associated with oceanic crust.

Cross sections along the Gabon Basin have been 2D-gravity modeled using the GMSYS software (@Geosoft). This program calculates gravity response from a given geological model. Such a model extends to "infinity" in the direction of the profile $( \pm$ $30,000 \mathrm{~km}$ ) in order to eliminate edge effects. 2D blocks and surfaces are presumed to extend to infinity in the strike direction. Methods used to calculate the gravity model response are based on the routines of Talwani et al. (1959) and make use of the algorithms described in Won and Bevis (1987). Two-and-half dimensional calculations are based on Rasmussen and Pedersen (1979). GM-SYS uses a 2D, flat-Earth model for gravity calculations. A constant deviation (DC shift) is subtracted from the calculated gravity to match the observed data. This is necessary because calculated values correspond to an absolute gravity calculation in reference to a model extending to $30,000 \mathrm{~km}$ in $\pm x$ direction, and to an arbitrary depth (45 km). The DC shift is automatically calculated to minimize the root mean square (RMS) error between measurement and simulation.

Densities of sediments and crustal bodies have been chosen in accordance to petrophysical studies (Dobrin \& Savit, 1988). Gravity modeling, in the Benguela and Namibe basins and in the ultra-deep offshore South Gabon (Grant, private communication, 2000), provides additional constraints on the density distribution. Table 1 summarizes values used for each lithologic unit. 


\section{Seismic data description}

Table 2 summarizes the main seismic features of the picked horizons associated with the intra and subcrustal units and the sedimentary packages (sea bottom, top and base salt, syn-rift base) (Figs 3, 4, 5 and 6).

\subsection{The sedimentary sequence}

In the South Gabon Basin, the upper and lower limits of the Aptian evaporites are imaged by clear and strong seismic reflections (Dupré et al., 2007). The sedimentary column has been divided there into three sequences: post-salt, evaporites and presalt series. The basement-sediment transition is scarcely visible due to the overlying evaporites, and could be picked only locally. Elsewhere, the top basement has been approximated to a constant interval TWT below the base of the salt, in accordance with information derived from available wells. This approximation will be subsequently tested with gravity modeling. In the northern part of the South Gabon Basin (profile 2, Figs 4 and $6 \mathrm{~b}$ ), the pre-salt sequence thickness reaches $\sim 200$ to 400 $\mathrm{ms}$ in TWT i.e. 0.5 to $1 \mathrm{~km}$ in depth. A proximal well (penetrating the eastern limit of section $2 \mathrm{~A}$, Figs 2 and $6 \mathrm{~b}$ ) drilled $5.1 \mathrm{~km}$ of sediments down to the Aptian Gamba Formation, the first post-rift deposit ( $118 \mathrm{Ma}$, Teisserenc \& Villemin, 1990). This thickness is in accordance with the depth conversion which corresponds there to a total sedimentary thickness of $5.3 \mathrm{~km}$. At this location, the syn-rift deposits are relatively thin $(\sim 200 \mathrm{~m})$. Along the most southern line (profile 1, Fig. 5) the pre-salt sediments are significantly thicker, between 500 and $1000 \mathrm{~ms}$ TWT (i.e. 0.5 to $2.5 \mathrm{~km}$ in depth) decreasing towards the ocean (Fig. 6c). Maximum thicknesses are found under the continental platform and reach $1400 \mathrm{~ms}$ in TWT, i.e. almost $3.0 \mathrm{~km}$ (Fig. 5, section 1A). A well located at the shelf break (line 1, section 1A, Fig. 6c) penetrates $3.3 \mathrm{~km}$ of sediments down to the syn-rift Barremian Dentale Formation. At this position, the total sedimentary thickness inferred from the depth conversion represents $5.3 \mathrm{~km}$ (Fig. 6c), indicative of $2.0 \mathrm{~km}$ of syn-rift deposits.

In the North Gabon Basin located at the northern edge of the Aptian salt basin (Fig. 2) thinner evaporites were deposited. The base of the sedimentary column is therefore more visible and could be easily picked all along the line (Fig. 3). However, no distinction between pre-salt, salt and post-salt deposits could be established due to the thin evaporite layer. A decrease of the sedimentary thickness is observed from $\sim 6 \mathrm{~km}$ at the shelf break to $\sim 2 \mathrm{~km}$ towards the ocean (Fig. 6a). The deepest basins are located under the platform at the eastern side of the profile. One of them reaches a depth of $8-9 \mathrm{~km}$ and extends along a distance of $\sim 10 \mathrm{~km}$ (section 3A, Fig. 6a).

\subsection{The crustal events}

The most relevant deep seismic feature is a clear reflector characterized by a strong change in seismic amplitude (Figs 3 to 5). We name it the ' $G$ ' reflector. Nearly continuous, as noted by Rosendahl et al. (1991), this reflector is of less quality in areas characterized by thick evaporite layers (Wannesson et al., 1991). This G reflector runs in the 7-10 s TWT window (see along profiles 3 and 2 in Figs 3 and 4, respectively). In the most southern investigated part of the basin, despite a lower seismic resolution of the easternmost section (line 1, Fig. 5a), the $\mathrm{G}$ reflector is interpreted to lie around a depth of $\sim 10 \mathrm{~s}$ TWT from the coastal area to the oceanic crust area. Along the studied seismic lines, the $G$ reflector locally exhibits minor discontinuities over a few kilometres or some layering (e.g. in Fig. 4, section $2 \mathrm{~B}$ at a depth of $8 \mathrm{~s}$ TWT and in Fig. 5, section 1C at a depth of 9-10 s TWT). The northern 
profile displays the clearest and most continuous $\mathrm{G}$ reflector, most likely because of the absence of massive salt deposits (Fig. 3a). Many discontinuous reflectors are visible above the $\mathrm{G}$ reflector showing a chaotic spatial distribution. These intracrustal reflections are observed along all seismic lines from the continental crust to the oceanic crust through the transitional zone. A few of the strongest reflections have been marked (see e.g. Fig. 5, section 1A).

A good knowledge of the Moho position is of obvious importance as it directly influences estimates of crustal thinning experienced during rifting, and consequently, the overall thermal and subsidence evolution of the margin. In the absence of any other consistent seismic reflectors below the sedimentary succession, it is tempting to interpret the $G$ reflector as the Moho level. The $G$ reflector has been identified in the N'Komi fracture zone area (Fig. 2) by a separate multi-channel seismic dataset, and interpreted in some places as the Moho and in some others as the top of the lower crust by Wannesson et al. (1991). Preliminary published works on the Probe seismic survey had interpreted this highly reflective event as the Moho (Meyers \& Rosendahl, 1991; Rosendahl et al., 1991). Watts \& Stewart (1998) conducted rifting modeling study based on backstripping (with sedimentary thicknesses derived from a shallow seismic profile, Fig. 2) to calculate the amount of crustal thinning, and subsequently a gravity anomaly which can be compared to the observed signal. Their gravity modeling results were in accordance with the first results published by the Probe workers. Following studies, involving reprocessing of the data, have questioned this interpretation (Meyers et al., 1996; Rosendahl \& Groschel, 1999; Rosendahl \& Groschel, 2000; Rosendahl et al., 1992). Rosendahl \& Groschel (2000) who firstly and extensively worked on the dataset faced difficulties with the identification, the significance and the meaning of this deep reflector. They concluded that it could not represent the crust-mantle boundary in a regional context. We will test this interpretation with gravity modeling. They interpreted this level to be the transition between upper crustal sheets and lower crustal lenses.

Oceanic crustal bodies covered with sediments have been identified at the southwestern ends of the profiles (see sections 2D and 1C in Figs 4 and 5, respectively). Seismic data do not indicate any obvious change in seismic facies, which could reflect a clear transition between the continental and oceanic crust. Regarding the gravity modeling, we applied a crustal density zonation from the NE to SW direction. The thinned continental crust under the platform gives way oceanwards to a transitional zone characterized by higher crustal density before reaching the oceanic crust.

\section{Margin configuration offshore Gabon}

Along the Gabon Margin, the variations of the crustal density, the Moho level and the depth of syn-rift base are not determined in details. Since 1) a gravity signal is not the result of a unique margin configuration, and 2) more than one parameter can varied, the primary attempt was to reproduce the free air anomaly by investigating variations in crustal densities and Moho depth. A second step in the modeling examined the effects of sedimentary depth variations in order to improve the match with the observed data. Different margin configurations were gravity modeled (Figs 7 to 10). A first series introduced lateral density heterogeneities within the crust. A Moho level associated with the $G$ reflector and different tabular and wedge crustal shapes were modeled (e.g. Figs $8 \mathrm{a}$ and $9 \mathrm{a}$ ). A second series investigated the effects of density variations with depth, assuming the $G$ reflector to be a density contrast level within 
the crust itself, dividing the crust into an upper and a lower part (e.g. Figs 8b, 9b and 10).

\subsection{Density heterogeneities within the crust}

\subsubsection{Implications on thinning factors}

Crustal thicknesses and thinning factors were derived from the seismic cross sections assuming the $\mathrm{G}$ reflector to be the Moho (Fig. 6). The Moho level would then be at relatively shallow depths. In the proximal domain, the Moho would lie between $\sim 30$ (Fig. 6c, line 1A) and $\sim 20 \mathrm{~km}$ depth (Fig. 6b, line 2A). Towards the ocean, the Moho would become shallower and reach the depth of $\sim 15 \mathrm{~km}$ at the oceancontinent boundary. Consequently, along the two most northern profiles, thickness of the thinned continental crust would decrease towards the ocean from $\sim 20$ to $\sim 8 \mathrm{~km}$ (line 3, Fig. 6a) and from $\sim 16$ to $\sim 8 \mathrm{~km}$ (line 2, Fig. 6b), respectively. Along the southern profile, the crust would be relatively thicker (line 1, Fig. 6c), reaching $28 \mathrm{~km}$ under the continental platform and decreasing to $6 \mathrm{~km}$ towards the ocean. In this view, the two northern profiles are characterized by high $\beta$ factors comprised between 1.5 and 2.5. These $\beta$ values appear very high in the proximal part of the margin where the continental crust is expected to 1 ) be not so much thinned unless numerous faults dissect the margin and to 2) contrast significantly with the deeper offshore areas. The easternmost part of the southern line exhibits smaller $\beta$ factors ranging from 1 to 1.5. However, because of a low seismic resolution there, this last result has to be taken with caution. Interpreting the 7-10 s TWT reflector as the Moho level implies a shallow Moho depth, and consequently, high amount of thinning. It is worth noting that our results even minimized the $\beta$ factor values, and therefore the crustal thinning, because 1 ) estimated crustal thickness are maximized considering the probably over-thin syn-rift thickness (Fig. 6) and 2) we assume an initial continental crustal thickness of $30 \mathrm{~km}$ only.

\subsubsection{Implications on gravity}

Lateral density heterogeneities within the crust assuming different Moho levels were investigated by gravity modeling. One of the goals was to determine if the crustal configuration assuming the $G$ reflector to be the Moho was compatible or not with observed gravity data. The gravity results are shown in Fig. 7 for the three deep seismic sections (Fig. 6) with indications of the adopted density values (Table 1). A large error of $-30-40 \%$ is observed between the modeled gravity signal and the data. We therefore investigated other margin configurations by modifying the depth of the Moho, still applying lateral crustal density variations.

\subsubsection{North Gabon Basin.}

A continental crust in the proximal domain, thicker than the $20 \mathrm{~km}$ previously assumed, was gravity modeled, accentuating thus the wedge shape of the crust (Fig. 7a). No matter what the Moho depth and the lateral crustal density variation are, the produced gravity signal does not coincide with the observed data. Other scenarios were investigated assuming the Moho deeper than the $G$ reflector by shifting this level downwards all along the section. None of the vertical shifts mimics the observed data. Assuming a Moho $5 \mathrm{~km}$ deeper than the $\mathrm{G}$ reflector produces a large error of $\sim 34 \%$ between the observed and calculated gravity signal (Fig. 8a). Tabular and 
wedge crustal shapes associated with lateral variation of the crustal density are not satisfactory to explain the observed gravity anomaly in the North Gabon Basin.

\subsubsection{Upper South Gabon.}

The hypothesis of a higher crustal thickness at the eastern limit of the profile was tested with gravity modeling (Fig. 9a). Instead of the $16 \mathrm{~km}$ previously derived from seismic interpretation (Fig. 6b), we imposed a thickness of $20 \mathrm{~km}$. In order to reproduce the first order observed gravity signal, no significant crustal thinning in the proximal domain is required. From the eastern side of the shelf towards the ocean, the crust would thus remain $\sim 20 \mathrm{~km}$ thick along a wide lateral zone of $\sim 150 \mathrm{~km}$ (Fig. 9a). Crustal thickness would then gradually decrease down to $\sim 10 \mathrm{~km}$ along a distance of $\sim 60 \mathrm{~km}$. Two modeled crustal density configurations are comparable to the observed FAA. The first one involves a sharp transition between the continental and oceanic crust and the second one a progressive lateral increase of the crustal density. In both of these cases, a $\sim 10 \mathrm{~km}$ thick crust $\left(2.8\right.$ or $\left.2.82 \mathrm{~g} / \mathrm{cm}^{3}\right)$ is required at the western edge of the profile, associated with a $\sim 2-3 \mathrm{~km}$ thin oceanic crust (Fig. 9a). These scenarios are not however supported by seismic data. Moreover, similarly to the previous result (Fig. 7b), the misfit in the easternmost part of the continental shelf remains. The modeled gravity signal is there lower than the observed data. Only the presence of denser material at the base of the crust, for instance an intrusion of a magmatic body combined with deep depocenters east of the section, could explain the observed anomaly (Fig. 9a). We further investigated the effects of a crust thicker than $20 \mathrm{~km}$ in the eastern part. Gravity modeling results are similar to the ones of the previous model (Fig. 9a) and are still not satisfactory. A $25 \mathrm{~km}$ thick continental crust in the east of $25 \mathrm{~km}$ requires too high crustal thickness in the westernmost part of $15 \mathrm{~km}$ at the ocean-continent boundary.

\subsubsection{Middle South Gabon Basin.}

The southern profile was gravity modeled similarly to the two others by testing downward shift of the $G$ reflector (by $5 \mathrm{~km}$ ) and lateral variation in the crustal thickness. None of these models is able to reproduce the first order observed gravity data, no matter what the lateral crustal density variation and the distribution of the sedimentary basins are. The proximal area is characterized by a high peak anomaly of $30-40 \mathrm{mGal}$ over a narrow distance of $\sim 20 \mathrm{~km}$ (Fig. 10). The thick $(\sim 27 \mathrm{~km})$ continental crust derived from the depth-converted section (Fig. 6c) and associated with a density of $2.7 \mathrm{~g} / \mathrm{cm}^{3}$ does not represent enough dense material to reproduce the high amplitude gravity anomaly observed there. This gravity signal possibly reflects the presence of a deep denser source beneath, and would imply a thin crustal thickness and relatively shallow sedimentary basins.

\subsubsection{Conclusions}

Several margin configurations involving different Moho depths and density heterogeneities within the crust were gravity modeled, but unsuccessfully. Gravity modeling issue is not to determine margin parameters in details but it provides insights on how realistic or not are specific crustal and sedimentary configurations. Crustal structures associated with a Moho level at the depth of the $G$ reflector fail to reproduce a gravity signal similar to the observed data. Gravity modeling supports the conclusion drawn from the estimation of crustal thickness and thinning factors, namely that the Moho cannot coincide with the strong seismic reflector $(G)$ observed. This result corroborates the ones based on seismic analysis and performed by Rosendahl \& Groschel (2000). 


\subsection{Density heterogeneities within the upper and lower crust}

Based on our previous results, the Moho level should be located deeper than the $G$ reflector. Further models investigated the effects on gravity of the presence of a denser lower crustal body below the $\mathrm{G}$ reflector interpreted as an intracrustal level.

\subsubsection{North Gabon Basin}

In the North Gabon Margin, gravity modeling involving a lower crust is not satisfactory to reproduce the observed gravity signal. Fig. 8b displays a margin configuration associated with lateral density heterogeneities within the upper and lower crust compatible with the observed gravity data (error of $2 \%$ ), but complex and unrealistic. The density values of the lower crust were set free and inversion modeling was used to obtain an optimal fit with the observed gravity data. The required lower crust thus consists of an unrealistic succession of 30 to $50 \mathrm{~km}$ wide blocks associated with density varying between 2.7 and $3.2 \mathrm{~g} / \mathrm{cm}^{3}$.

\subsubsection{South Gabon Basin}

\subsubsection{Upper South Gabon Basin.}

Realistic margin configuration involving a two-layered crust delimited by the $G$ reflector was successfully gravity modeled (error of $2 \%$ only, Fig. $9 b$ ). In the east, the required lower crust is thus $2.5-3.0 \mathrm{~km}$ thin and rapidly increases in thickness towards the ocean to $7-9 \mathrm{~km}$. The lower crust does not extend all along the profile but is restricted to a distance of $\sim 160 \mathrm{~km}$ (Fig. 9b). A uniform lower crustal density of $2.85 \mathrm{~g} / \mathrm{cm}^{3}$ is satisfactory to reproduce the gravity anomaly. A decrease of this density by $0.5 \mathrm{~g} / \mathrm{cm}^{3}$ would increase the modeled Moho depth by a few kilometers. In the west, the required oceanic crust is relatively thick reaching $\sim 10 \mathrm{~km}$. Deeper presalt depocenters in the eastern side along a distance of $\sim 60 \mathrm{~km}$ are additionally required. These pre-salt sedimentary basins are on average $\sim 3 \mathrm{~km}$ thick, reaching 4 $\mathrm{km}$ at maximum. From the coastal to the ocean-continent boundary area, the total crustal thickness varies thus from around $21 \mathrm{~km} \pm$ a few $\mathrm{km}$ along $\sim 180 \mathrm{~km}$, and rapidly decreases down to $10 \mathrm{~km}$ in the westernmost $\sim 40 \mathrm{~km}$. The crustal thinning is then directly related to the geometry of the lower crust. The lower crust is not present in the deep water area along $\sim 50 \mathrm{~km}$ and the depths there are characterized by mantle material with a $3.2 \mathrm{~g} / \mathrm{cm}^{3}$ density.

\subsubsection{Middle South Gabon Basin.}

Similarly to the Upper South Gabon area, the best and only margin configuration compatible with the observed gravity signal implies a two-layered crust associated with lateral density heterogeneities (error of 5\%, Fig. 10). This result is not incoherent with seismic data because of poor seismic resolution there (Fig. 5). Under the shelf and along a distance of $\sim 40 \mathrm{~km}$, the required lower crust then presents a bulge and is almost $15 \mathrm{~km}$ thick. Towards the ocean, the lower crust becomes thinner with an average thickness of $\sim 7 \mathrm{~km}$. In contrast to the northern profile in the Upper South Gabon Basin (Fig. 9b), the total crustal thickness significantly decreases from the coastal area towards the ocean from $\sim 30$ to $\sim 10 \mathrm{~km}$. Additionally, a 5-6 km thicker pre-salt sedimentary basin is required along a distance of $\sim 40 \mathrm{~km}$ in the shelf break area. Similarly to the Upper South Gabon profile, a deep sedimentary basin is required in the easternmost side to better adjust the high value of the gravity anomaly observed on the continental shelf (Fig. 10). 


\subsubsection{Conclusions}

Gravity modeling helps us to determine how realistic it is to consider an upper and lower crust delimited by the $G$ reflector. Gravity modeling results are significantly different between the North and the South Gabon Basin. In the North Gabon, we are not able to draw strong conclusions on the crustal structure of the margin. Our seismic and gravity analysis suggests however that the $G$ reflector is rather an intracrustal level than the Moho. In the South Gabon Basin, gravity modeling provides insights on the margin structure with the presence of high density lower crustal body beneath the $\mathrm{G}$ reflector.

\section{Discussion}

\subsection{Significance of the $\mathrm{G}$ reflector}

Distinction between a lower crust and an upper crust characterized many places, especially in continental domains (e.g. Reston, 1990; Transalp Working Group, 2002). On seismic, the lower crust is commonly imaged by a highly reflective layered body in contrast to the upper crust and uppermost mantle, which both appear almost transparent (e.g. Collier et al., 1994; Matthews \& Cheadle, 1986). Offshore Gabon there is no apparent reflective lower crust. Only a single and strong reflector can be observed delimitating an upper from a lower crust, both of them having a similar seismic facies. This high reflective seismic event is more or less continuous from the coastal to the ocean-continent boundary area, and is recorded along strike over large distances from Cameroon (Meyers et al., 1996), Gabon (e.g. Rosendahl et al., 1991; Wannesson et al., 1991) to Angola (Boavida et al., 2000; Boavida et al., 2001; Vågnes et al., 2000). Our seismic and gravity analysis suggests that this reflector most likely does not represent the transition between the crust and the mantle. The G reflector is interpreted as an intracrustal level, separating an upper crust from a lower denser one. The lateral density variations in the lower crust inferred from our gravity modeling may be associated with the presence of several ductile lenses (Rosendahl \& Groschel, 2000). The high variability of 1) the seismic signature along strike from line to line (Rosendahl et al., 1991) and 2) the deformational behavior of the upper and lower sheets (Rosendahl \& Groschel, 2000) is additionally reflected in the different geometry and density of the lower crust along the studied seismic lines. Why does the reflection seismic record the density transition between upper and lower crust and not the Moho level? The opposite situation seems to be more common. A good understanding of the formation of this high density body and the type of rocks of which it is composed, would contribute to an answer.

\subsubsection{Pre-rift event.}

In the Valencia Trough, Watts et al. (1990) suggested that the observed reflective lower crust has been in place prior to rifting. Offshore Gabon, a pre-rift event cannot be accountable for the formation of a dense lower crustal body. Indeed, the margin has been affected by rifting/drifting since its formation in the Early Cretaceous. No other tectonic events than those associated directly with the opening of the South Atlantic could have affected the crust and obscured seismically the Moho level. 


\subsubsection{Serpentinite.}

Beneath the tilted fault blocks of the Galician rifted margin, a strong, clear and quite continuous event is recorded on seismic (Boillot et al., 1992; Hoffman \& Reston, 1992). The fact that the Galicia Margin is relatively sediment starved makes possible sampling of the deep crustal levels by drilling. This deep reflector is known to be some form of basement feature. Some authors attribute this level to represent a major detachment fault, which was active during rifting (Hoffman \& Reston, 1992). Some other authors, e.g. Boillot et al. (1992), suggest that the strong reflector correlates with the top of a serpentinite body and represents the tectonic contact between the continental basement and serpentinized peridotites. According to these latter, the serpentinite would result from syn-rift unroofing and hydrothermal transformation of mantle rocks. As serpentinized peridotite can have density and seismic velocity comparable to those of the lower crust, they suggest that undercrusting by serpentinite could play a part in building the lower seismic crust in highly thinned continental rifted areas. In a closer but significantly different tectonic setting, the Rio Muni transform margin, Wilson et al. (2003) suggest that the protooceanic crust offshore Equatorial Guinea is composed of serpentinized peridotite segments with density of 3.08 and $3.10 \mathrm{~g} / \mathrm{cm}^{3}$.

\subsubsection{Underplating.}

Offshore South Gabon Margin, the high density layer below the $G$ reflector could possibly represent ultra mafic serpentinized rocks or high grade metamorphic crustal rocks. However, based on its density, geometry, spatial distribution and the crustal configuration of the surroundings, we are inclined to interpret this lower crustal body as the result of mafic magma underplating of the continental crust that has been thinned during extension. Dike and sill intrusion and partial melting have probably accompanied the formation of this underplated body. In this view, the thermal anomalies associated with magmatism, accompanied or not by lower crustal flow, could have diminished the reflectivity of the Moho level and, at the same time, created a new transition above, which is observed on seismic as the $\mathrm{G}$ reflector.

These thermal anomalies would be directly related to the rifting rather than to local and isolated deep-seated sources. Subsidence analysis performed in the South Gabon Basin has highlighted the occurrence of similar thermal anomalies (Dupré et al., 2007). Indeed, the Gabon Margin is characterized by a post-rift subsidence unexpectedly large compared to the syn-rift subsidence. These subsidence patterns appear to be strongly controlled by the rifting process and related to the early rifting thermal state of the lithosphere, namely a high thermal anomaly in the mantle part of the lithosphere. This scenario is additionally supported by 2D forward numerical modeling simulating the thinning of the South Gabon rifted Margin and the subsidence history and stratigraphy of the corresponding extensional basins (Dupré, 2003; Dupré et al., 2001). The consequences of a high thermal anomaly in the mantle part of the lithosphere during the early rifting stage on the margin configuration are consistent with our seismic and gravity results. This high thermal anomaly could have 1 ) had a strong impact on the crust causing significant thinning together with the formation of higher density rocks in it lower parts, 2) restricted the syn-rift subsidence that would therefore be associated with shallow syn-rift depocentres and 3) accentuated post-rift subsidence rates.

An insufficient signal penetration can possibly prevent from imaging clearly the Moho (Barnes, 1994). Offshore Gabon, this is probably accentuated by the scattering of the seismic energy due to the presence of evaporites. Data indicate there a higher acoustic impedance contrast between the upper crust and the lower crust than between the lower crust and the mantle. Based on a detailed seismic analysis of 
numerous seismic lines acquired in the Gabon Margin, Rosendahl \& Groschel (2000) concluded that the rifting of the margin seems to involve brittle, upper continental crustal sheets overlying a series of ductile lower sheets with their roof corresponding to the deep reflector. Following the reasons given by Meyers et al. (1996), the Moho level may be in some cases reset, perhaps by formation of partial melt (Rosendahl et al., 1992), ultramafic hydration (Boillot et al., 1992), or mafic magma underpating and dike intrusion.

\subsection{Comparison with the South Atlantic salt basins}

Our results have been compared with studies performed along the African side in Gabon (Rosendahl \& Groschel, 1999; Rosendahl et al., 1991; Rosendahl et al., 1992) and in Angola (Boavida et al., 2000; Contrucci et al., 2004; Moulin, 2003; Moulin et al., 2005), and along the conjugate margin in northeastern Brazil (Mohriak et al., 1998; Mohriak et al., 1995). The crustal structures of these South Atlantic basins have strong similarities with the offshore Gabon margin configuration derived from our seismic and gravity analysis.

\subsubsection{Gulf of Guinea.}

Reprocessing of deep seismic lines of the Probe survey (migration and post-stack reprocessing) provide a better image of deep structures, and in particular, of faulting of the thinned continental crust (Meyers et al., 1996; Rosendahl \& Groschel, 1999; Rosendahl \& Groschel, 2000). From the Douala Basin to the South Gabon Basin, the associated results support the presence of upper brittle crustal sheets overlying a series of more ductile lower sheets. The $\mathrm{G}$ reflector that separates these two crustal layers does not appear, as previously (e.g. Rosendahl et al., 1991), as a single and laterally coherent reflector. Seaward and landward dipping faults characterize the upper crust, which is generally non-reflective. Dip-slip faults in the thinned continental crust appear to curve at depth and sole into lower crustal reflection bands or to cross the interpreted Moho reflection at low angle. Geometry of the lower crustal sheets is quite variable from line to line (Rosendahl \& Groschel, 1999), in coherence with our gravity modeling results (Fig. 11).

\subsubsection{Angola.}

The acquisition of high quality reflection and refraction seismic data offshore Angola provides interesting insights on the deep structure of the margin. Velocity models of structures below the salt suggest the presence of an abnormal layer characterized by high energy reflectors and associated with velocities comprised between 7.2 and 7.4 to $7.8 \mathrm{~km} / \mathrm{s}$ (Boavida et al., 2000; Contrucci et al., 2004; Moulin et al., 2005). This layer is overlain by a transparent seismic unit. Contrucci et al. (2004) suggest that this high velocity layer may correspond either to 1) part of the lower crust or 2) serpentinized mantle. The Angola anomalous velocity zone presents some similarities with the offshore Gabon high density layer. If the $G$ reflector represents a density contrast, it should also represent a velocity contrast. In addition, both lower crustal bodies from offshore Gabon and Angola have a similar geometry and spatial distribution. They are both located beneath an upper crustal layer and extend laterally over large distance, i.e. along $\sim 100 \mathrm{~km}$, from the proximal domain, where the continental crust is thinned, towards the ocean (Contrucci et al., 2004; Moulin et al., 2005). However, the high velocity layer offshore Angola has a lower thickness and disappears towards the ocean in the middle of the thinned continental crust domain. We are more inclined to think, to the light of our study, that along the Gabon Margin, the layer below the strong reflection corresponds to the lower crust than serpentinized mantle. We consider additionally that if this strong reflector 
corresponds to the Moho, too high thinning factors characterize the rifting of the margin. It is also worth noting that, in addition to the crustal geometry, the overall architecture of the sedimentary deposits is very much comparable from Gabon to Angola (Fig. 11). The absence of wide and deep sedimentary basins and the eastern localisation of the main depocenters seem also to characterize the Angolan basins. The tilted blocks are of limited size and are exclusively present in the upper part of the slope, near the shelf break area, where the crustal thinning occurs (Moulin et al., 2005). Elsewhere, farther to the ocean, the sub-salt reflectors are flat. The continental crust thins very abruptly over a lateral distance of less than $50 \mathrm{~km}$, from $\sim 30 \mathrm{~km}$ below the continental shelf to less than $10 \mathrm{~km}$ (Contrucci et al., 2004; Moulin et al., 2005).

\subsubsection{Brazil.}

Along the offshore Sergipe-Alagoas and Jacuípe basins, located on the conjugate margin in northeastern Brazil, regional seismic reflection profiles extending from the coastline towards the ocean were integrated with gravity data (Mohriak et al., 1998; Mohriak et al., 1995). Their results corroborate the main conclusions of our seismic and gravity analysis performed offshore Gabon: the presence of a high density layer is required below the upper crust. Mohriak et al. (1998) associated this deep body with lower crust or underplating.

\section{Conclusions}

Deep seismic analysis coupled with gravity modeling provides interesting insights on the crustal structure of the Gabon Margin. Despite limitations due to the 2D approach and the non-unique nature of the solutions, gravity modeling allows us to discriminate between realistic and unrealistic crustal configurations.

\subsection{Moho position}

Based on combined seismic and gravity analysis, we came to the following conclusions: 1) the deep $G$ reflector visible on deep seismic in the 7-10 s TWT window cannot represent the transition between the crust and the mantle and 2) the Moho level has to be deeper. The $G$ reflector can be regarded as an intracrustal reflector that delimits an upper crust from a denser lower crust.

\subsection{Lateral crustal thickness variation along the coast}

Along the South Gabon Basin, crustal thicknesses derived from seismic and gravity suggest a relatively sharp and narrow transition between the unthinned and the thinned continental crust. Similar crustal transition has been also determined along the conjugate offshore Brazilian basins, the Sergipe-Alagoas and Jacuípe basins (Mohriak et al.,1998). Similar crustal geometry is revealed by deep reflection and refraction seismic data along the Angola Margin, where the crust sharply thins from 30 to $10 \mathrm{~km}$ over a narrow zone (c.a. $50 \mathrm{~km}$ ) (Contrucci et al., 2004; Moulin et al., 2005). 


\subsection{Syn-rift sedimentary distribution}

The deep seismic analysis does not fully resolve the syn-rift distribution and the following conclusions are tentative and gravity model-driven. Sedimentary distribution appears relatively uniform along the coast from the north to the south, with thicknesses varying mainly between 3 and $5 \mathrm{~km}$. Deepest basins are associated with the thickest pre-salt deposits and are located in the northeastern part of the margin. Two main depocenters can be distinguished, separated by a basement high. A first deep pre-salt basin is located on the easternmost side of the continental shelf reaching 7 to $8 \mathrm{~km}$ in thickness. A second major basin is located under the western side of the continental shelf, below the shelf break area. In the South Gabon Basin, this basin reaches on average a depth of $\sim 8 \mathrm{~km}$ and extends along a distance of 40 $60 \mathrm{~km}$.

\subsection{Rifting and crustal thinning}

Crustal thinning factors $(1 / \beta)$ have been derived from geological models inferred from seismic and gravity analysis. A positive correlation is observed between the amount of crustal thinning and the depth of the sedimentary basins. $\beta$ factors are relatively high whereas the sedimentary section is relatively thin. The deepest sedimentary basins are associated with crustal $\beta$ factors varying between 1.3 and 1.5. It is worth noting that the configuration of the rifted Gabon Margin presents unexpected features. Whereas the thinning of the crust appears quite significant, the syn-rift sedimentary infill is not associated with thick deposits. This configuration seems to extend farther to the south in the Angolan basins where a small amount of tilted blocks and associated syn-rift normal faults has been identified on reflection and refraction seismic (Contrucci et al., 2004; Moulin et al., 2005). Based on seismic and gravity data analysis, we suggest that the thinning offshore Gabon may possibly be related to a high thermal anomaly in the mantle part of the lithosphere in the early stage of the rifting (Dupré, 2003; Dupré et al., 2007). This thermal anomaly may be accountable for 1) the underplated body identified at present as the high density lower crust and subsequently leading to 2 ) the development of shallow depth syn-rift sedimentary basins due to the uplift of the margin and 3) the acceleration of the subsidence and sedimentation rates during the post-rift period.

\section{Acknowledgements}

We are grateful to Norsk Hydro for funding this study and giving access to West Africa data, gravity, seismic and wells, and related internal reports. We thank Western Geco in particular J. Elliot and P. Williams for providing authorisation for deep seismic lines publication. In the framework of a close collaboration between the Norsk Hydro Research centres of Bergen, Oslo and Luanda, the University of Bergen, the University of Rennes and the Vrije Universiteit of Amsterdam, we would like to thank all the participants, especially Nils Telnæs, Chris Dart, Linn Arnesen, Arnd Wilhelms, Erling Vågnes, Ridvan Karpuz, John Gjelberg, Walter Wheeler, Bjørn Pilskog, Geoffrey Grant, and Joaquim Boavida. Sylvie Leroy from the Institut des sciences de la Terre de Paris is thanked for the use of software facilities. We would like to thank Tim Minshull and Robert Whitmarsh for earlier reviews of the manuscript, and an anonymous reviewer. 


\section{References}

Barnes, A.E., 1994. Moho reflectivity and seismic signal penetration, Tectonophysics, 232, 299-307.

Binks, R.M. \& Fairhead, J.D., 1992. A plate tectonic setting for Mesozoic rifts of West and Central Africa, Tectonophysics, 213, 141-151.

Boavida, J., Morais, E., Catanha, M., Caholo, I., Baptista, C., Biella, G., Boniolo, G., Cattaneo, M., Corsi, A., De Franco, R., Lozej, A., Pasta, M., Mendes-Victor, L., Matias, L., Sibuet, J.C., Géli, L., Houzé, H., Contrucci, I. and Moulin, M., 2000, First insights into the deep structure of the northern Angolan continental margin by refraction/wide angle reflection seismic data. GeoLuanda 2000 Abstracts: 31.

Boavida, J., Vågnes, E., Jeronimo, P., de Brito, M., Inkollu, M., Peliganga, J. \& Symonds, M., 2001. Crustal structure, rift tectonics and pre-salt stratigraphy beneath the ultra deep water area offshore Angola; results from reprocessed seismic data, Annual Meeting Expanded Abstracts AAPG, 20-21.

Boillot, G., Beslier, M.O. \& Comas, M.C., 1992. Seismic image of undercrusted serpentinite beneath a rifted margin, Terra Nova, 4, 25-33.

Brice, S.E., Cochran, M.D., Pardo, G. \& Edwards, A.D., 1982. Tectonics and sedimentation of the South Atlantic rift sequence; Cabinda, Angola. AAPG Memoir, 34, 5-18.

Brink, A.H., 1974. Petroleum Geology of Gabon Basin, AAPG Bulletin, 58, 216-235.

Castro, A.C.M., 1987. The northeastern Brazil and Gabon basins; a double rifting system associated with multiple crustal detachment surfaces, Tectonics, 6, 727-738.

Collier, J.S., Buhl, P., Torne, M. \& Watts, A.B., 1994. Moho and lower crustal reflectivity beneath a young rift basin; results from a two-ship, wide-aperture seismic-reflection experiment in the Valencia Trough (western Mediterranean), Geophysical Journal International, 118, 159-180.

Contrucci, I., Matias, L., Moulin, M., Géli, L., Klingelhofer, F., Nouzé, H., Aslanian, D., Olivet, J.L., Réhault, J.P. \& Sibuet, J.C., 2004. Deep structure of the West African continental margin (Congo, Zaire, Angola), between 5 degrees $S$ and 8 degrees S, from reflection/refraction seismics and gravity data, Geophysical Journal International, 158, 529-553.

Davison, I., 1999. Tectonics and hydrocarbon distribution along the Brazilian South Atlantic margin, Geological Society Special Publications, 153, 133-151.

de Matos, R.M.D., 1992. The Northeast Brazilian rift system, Tectonics, 11, 766-791.

Dingle, R.V., 1999. Walvis Ridge barrier; its influence on palaeoenvironments and source rock generation deduced from ostracod distributions in the early South Atlantic Ocean, Geological Society Special Publications, 153, 293-302.

Dobrin, M.B. and Savit, C.H., 1988. Introduction to geophysical prospecting. McGraw-Hill Book Co., New York.

Dupré, S., 2003. Integrated tectonic study of the South Gabon Margin. Insights on the rifting style from seismic, well and gravity data analysis and numerical modelling, PhD thesis, Netherlands Research School of Sedimentary Geology, Vrije Universiteit, Amsterdam. ISBN 90-9017055-3.

Dupré, S., Bertotti, G. \& Cloetingh, S., 2007. Tectonic history along the South Gabon Basin: Anomalous early post-rift subsidence, Marine and Petroleum Geology, 24, 151-172.

Dupré, S., Bertotti, G., Wheeler, W. \& Cloetingh, S., 2001. Tectonic evolution of the Gabon-Angola Margin based on seismic, well and potential-field data and associated geophysical modelling. Geophysical Research Abstracts, 3, 685.

Gladczenko, T.P., Hinz, K., Eldholm, O., Meyer, H., Neben, S. \& Skogseid, J., 1997. South Atlantic volcanic margins, Journal of the Geological Society of London, 154, 465-470. 
Guiraud, R. \& Maurin, J.C., 1991. Le Rifting en Afrique au Crétacé inférieur; synthèse structurale, mise en évidence de deux étapes dans la genèse des bassins, relations avec les ouvertures océaniques péri-africaines, Bulletin de la Société Géologique de France, 162, 811-823.

Hadiouche, O. \& Jobert, N., 1988. Geographical distribution of surface-wave velocities and 3-D upper-mantle structure in Africa, Geophysical Journal of the Royal Astronomical Society, 95, 87-109.

Hoffman, H.J. \& Reston, T.J., 1992. Nature of the S reflector beneath the Galicia Banks rifted margin; preliminary results from prestack depth migration, Geology, 20, 1091-1094.

Jackson, M.P.A., Cramez, C. \& Fonck, J.-M., 2000. Role of subaerial volcanic rocks and mantle plumes in creation of South Atlantic margins: implications for salt tectonics and source rocks, Marine and Petroleum Geology, 17, 477-498.

Kampunzu, A.B. \& Popoff, M., 1991. Distribution of the main Phanerozoic African rifts and associated magmatism; introductory notes, in Magmatism in extensional structural settings; the Phanerozoic African Plate., pp. 2-10, eds. Kampunzu, A. B. \& Lubala, R. T., Springer-Verlag, Berlin, Federal Republic of Germany.

Karner, G.D., Driscoll, N.W., McGinnis, J.P., Brumbaugh, W.D. \& Cameron, N.R., 1997. Tectonic significance of syn-rift sediment packages across the GabonCabinda continental margin, Marine and Petroleum Geology, 14, 973-1000.

Mascle, J. \& Blarez, E., 1987. Evidence for transform margin evolution from the Ivory Coast-Ghana continental margin, Nature, 326, 378-381.

Matthews, D.H. \& Cheadle, M.J., 1986. Deep reflections from the Caledonides and Variscides west of Britain and comparison with the Himalayas, Geodynamics Series, 13, 5-19.

Mbina Mounguengui, M., Lang, J., Guiraud, M. \& Jocktane, O., 2002. Sedimentary dynamics and structural geology of pre-rift deposits of the interior basin of Gabon, Journal of African Earth Sciences, 35, 315-329.

Meyers, J.B. \& Rosendahl, B.R., 1991. Seismic reflection character of the Cameroon volcanic line; evidence for uplifted oceanic crust, Geology, 19, 1072-1076.

Meyers, J.B., Rosendahl, B.R., Groschel, B.H., Austin Jr, J.A. \& Rona, P.A., 1996. Deep penetrating MCS imaging of the rift-to-drift transition, offshore Douala and North Gabon basins, West Africa, Marine and Petroleum Geology, 13, 791-835.

Mohriak, W.U., Bassetto, M. \& Vieira, I.S., 1998. Crustal architecture and tectonic evolution of the Sergipe-Alagoas and Jacuípe basins, offshore northeastern Brazil, Tectonophysics, 288, 199-220.

Mohriak, W.U., Rabelo, J.H.L., de Matos, R.D. \& de Barros, M.C., 1995. Deep seismic reflection profiling of sedimentary basins offshore Brazil; geological objectives and preliminary results in the Sergipe Basin, Journal of Geodynamics, 20, 515-539.

Moulin, M., 2003. Etude géologique et géophysique des marges continentales passives: example du Zaïre et de l'Angola, PhD thesis, Université de Bretagne Occidentale, Brest.

Moulin, M., Aslanian, D., Olivet, J.L., Contrucci, I., Matias, L., Géli, L., Klingelhoefer, F., Nouzé, H., Réhault, J.P. \& Unternehr, P., 2005. Geological constraints on the evolution of the Angolan margin based on reflection and refraction seismic data (ZaiAngo Project), Geophysical Journal International, 162, 793-810.

Nürnberg, D. \& Müller, R.D., 1991. The tectonic evolution of the South Atlantic from Late Jurassic to present, Tectonophysics, 191, 27-53.

Popoff, M., 1988. Du Gondwana à l'Atlantique sud; les connexions du fossé de la Bénoué, avec les bassins du nord-est brésilien jusqu'à l'ouverture du golfe de Guinée au Crétacé inférieur, Journal of African Earth Sciences, 7, 409-431.

Rasmussen, R. and Pedersen, L.B., 1979. End corrections in potential field modeling. Geophysical Prospecting, 27: 749-760. 
Reston, T.J., 1990. The lower crust and the extension of the continental lithosphere; kinematic analysis of BIRPS deep seismic data, Tectonics, 9, 1235-1248.

Reyre, D., 1984. Evolution géologique et caractères pétroliers d'une marge passive: cas du bassin du Bas Congo-Gabon, Bulletin des Centres de Recherches Exploration Production Elf Aquitaine, 8, 303-332.

Rosendahl, B.R. \& Groschel, B.H., 1999. Deep seismic structure of the continental margin in the Gulf of Guinea; a summary report, Geological Society Special Publications, 153, 75-83.

Rosendahl, B.R. \& Groschel, B.H., 2000. Architecture of the continental margin in the Gulf of Guinea as revealed by reprocessed deep-imaging seismic data, Geophysical Monograph, 155, 85-103.

Rosendahl, B.R., Groschel, B.H., Meyers, J. \& Kaczmarick, K., 1991. Deep seismic reflection study of a passive margin, southeastern Gulf of Guinea, Geology, 19, 291-295.

Rosendahl, B.R., Meyers, J.B., Groschel, H. \& Scott, D., 1992. Nature of the transition from continental to oceanic crust and the meaning of reflection Moho, Geology, 20, 721-724.

Sandwell, D.T. \& Smith, W.H.F., 1997. Marine gravity anomaly from Geosat and ERS 1 satellite altimetry, Journal of Geophysical Research, 102, 10,039-010,054.

Smith, W.H.F. \& Sandwell, D.T., 1997. Global sea floor topography from satellite altimetry and ship depth soundings, Science, 277, 1956-1962.

Talwani, M., Worzel, J.L. and Landisman, M.G., 1959. Rapid gravity computations for two-dimensional bodies with application to the Mendocino submarine fracture zone (Pacific Ocean). Journal of Geophysical Research, 64: 49-59.

Teisserenc, P. \& Villemin, J., 1990. Sedimentary basin of Gabon; geology and oil systems, AAPG Memoir, 48, 117-199.

Transalp Working Group, 2002. First deep seismic reflection images of the Eastern Alps reveal giant crustal wedges and transcrustal ramps, Geophysical Research Letters, 29, 1-4.

Uchupi, E. \& Emery, K.O., 1991. Pangaean divergent margins; historical perspective, Marine Geology, 102, 1-28.

Vågnes, E., Boavida, J., De Brito, M., Inkollu, M., Geronimo, P., Symonds, M. \& The UDW Sub Salt Structure and Stratigraphy Project Team, 2000. Crustal structure, rift tectonics and pre-salt stratigraphy beneath the UDW area offshore Angola: preliminary results from reprocessed seismic data. GeoLuanda 2000 Abstracts, 138.

Wannesson, J., Icart, J.C. \& Ravat, J., 1991. Structure and evolution of two adjoining segments of the West African margin from deep seismic profiling, Geodynamics Series, 22, 275-289.

Watts, A. B. \& Stewart, J., 1998. Gravity anomalies and segmentation of the continental margin offshore West Africa, Earth and Planetary Science Letters, 156, 239-252.

Watts, A.B., Torne, M., Buhl, P., Mauffret, A., Pascal, G. \& Pinet, B., 1990. Evidence for reflectors in the lower continental crust before rifting in the Valencia Trough, Nature, 348, 631-635.

Wilson, P.G., Turner, J.P. \& Westbrook, G.K., 2003. Structural architecture of the ocean-continent boundary at an oblique transform margin through deepimaging seismic interpretation and gravity modelling: Equatorial Guinea, West Africa, Tectonophysics, 374, 19-40.

Won, I.J. and Bevis, M., 1987. Computing the gravitational and magnetic anomalies due to a polygon: algorithms and Fortran subroutines. Geophysics, 52: 232238. 


\section{Figure captions}

Figure 1 South Atlantic Ocean shaded morphology map derived from satellite bathymetry data (Smith \& Sandwell, 1997). Black stars stand for the studied area offshore Gabon and the Sergipe-Alagoas conjugate basins along the Brazil Margin.

Figure 2 Free Air anomaly map (1-minute grid resolution) along the Gabon Margin from Sandwell \& Smith (1997) with indications of the major isobaths (Smith \& Sandwell, 1997). Offshore and onshore geological information are reported. Shown are the three studied deep reflection seismic lines which extend from the proximal domain to the distal parts of the margin. Numbered 1, 2 and 3, they are displayed in Figs 5, 4 and 3, respectively.

Figure 3 North Gabon Basin deep reflection seismic profile (numbered 3) in ms TWT (a) and the corresponding interpretation (b) with zoom on the $G$ deep reflector (c). See Fig. 2 for location. Note the vertical exaggeration of 2.5. Seismic data courtesy of Western Geco.

Figure 4 South Gabon Basin deep reflection seismic profile (numbered 2) in ms TWT (a) and the corresponding interpretation (b) with zoom on the $G$ deep reflector (c). See Fig. 2 for location. Note the vertical exaggeration of 2.5. Seismic data courtesy of Western Geco.

Figure 5 South Gabon Basin deep reflection seismic profile (numbered 1) in ms TWT (above) and the corresponding interpretation (b). See Fig. 2 for location. Note the vertical exaggeration of 2.5. Seismic data courtesy of Western Geco.

Figure 6 Deep cross sections in $\mathrm{km}$ derived from the depth-converted seismic reflectors identified on the seismic lines of Figs 3, 4 and 5 with indications of the initial velocity $\left(V_{0}\right)$ and the rate of velocity change (k) (see Eq. 1) used. a) North Gabon Basin (profile 3). b) South Gabon Basin (profile 2). c) South Gabon Basin (profile 1). For significance of lithologic units, see Figs 3, 4 and 5. For profile locations, see Fig. 2.

Figure 7 Gravity modeling results assuming the $G$ reflector to be the Moho level along deep seismic lines running in a) the North Gabon Basin (line 3), b) the South Gabon Basin (line 2), and c) the South Gabon Basin (line 1). For location, see Fig. 2. Densities $\left(\mathrm{g} / \mathrm{cm}^{3}\right)$ applied in the model are indicated along each profile (see also Table 1). The error in \% between the observed FAA and gravity modeled signal is also specified on top of the modeled section.

Figure 8 North Gabon Basin gravity modelling results along line 3 (see Figs 2 and 3). Model derived a) by a downward shifting of the Moho of $5 \mathrm{~km}$ relative to the $G$ reflector and b) by addition of a lower crust below the $\mathrm{G}$ reflector. Legend, see Fig. 7.

Figure 9 Upper South Gabon Basin gravity modelling results along line 2 (see Figs 2 and 4). Model derived a) by a deeper Moho level relative to the $G$ reflector and $b$ ) by addition of a lower crust below the $\mathrm{G}$ reflector. Legend, see Fig. 7. 
Figure 10 Middle South Gabon Basin gravity modelling results along line 1 (see Figs 2 and 5). Model derived by addition of a lower crust below the $G$ reflector. Legend, see Fig. 7.

Figure 11 Structure of the Gabon Margin based on combined analysis of deep reflection seismic and gravity data along three investigated lines in the a) North Gabon Basin, b) Upper South Gabon Basin and c) Middle South Gabon Basin. The G reflector can be regarded as an intracrustal reflector that delimits an upper crust from a lower crust which is denser. Sedimentary basin (sed) and crustal thickness values (crust) are both indicated along the sections. Information on crustal thinning is reported with indications of the $\beta$ values (crustal thinning factors $1 / \beta), \beta_{\min }$ and $\beta_{\max }$ considering an initial unthinned crust of 30 and $34 \mathrm{~km}$, respectively (see text).

\section{Table captions}

Table 1 Density database used for the gravity modelling.

Table 2 Summary: seismic reflector characteristics. 


\begin{tabular}{|l|c|}
\hline \multicolumn{1}{|c|}{ Lithologic unit } & Density $(\mathbf{g . c m}$ \\
& $\mathbf{- 3}$ ) \\
\hline Water & 1.03 \\
\hline Post-salt sediments & 2.4 \\
\hline Salt & 2.2 \\
\hline Pre-salt sediments & $2.5-2.6$ \\
\hline Continental crust & 2.7 \\
\hline Transitional crust & 2.7 to 2.9 \\
\hline Oceanic crust & 3.0 \\
\hline Mantle & 3.2 \\
\hline
\end{tabular}




\begin{tabular}{|c|c|}
\hline Seismic horizon & Seismic character \\
\hline Top of the salt & - strong, continuous, high reflectivity \\
\hline Base of the salt & - clear, continuous, high reflectivity \\
\hline $\begin{array}{l}\text { Base of the syn-rift } \\
\text { (top of the crystalline } \\
\text { basement) }\end{array}$ & $\begin{array}{l}\text { - hardly visible on seismic } \\
\text { - picked below the base salt under } \\
\sim \text { constant TWT interval }\end{array}$ \\
\hline Intracrustal reflectors & $\begin{array}{l}\text { - discontinuous } \\
\text { - chaotic spatial distribution }\end{array}$ \\
\hline G reflector & $\begin{array}{l}\text { - strong, clear } \\
\text { - most continuous reflector (below the salt) } \\
\text { - picked in the 7-10 s TWT window } \\
\text { - locally discontinuities over a few km } \\
\text { - locally layering }\end{array}$ \\
\hline Sub-G reflectors & $\begin{array}{l}\text { - discontinuous } \\
\text { - horizontal over } 10 \mathrm{~km} \\
\text { - locally oblique }\end{array}$ \\
\hline
\end{tabular}




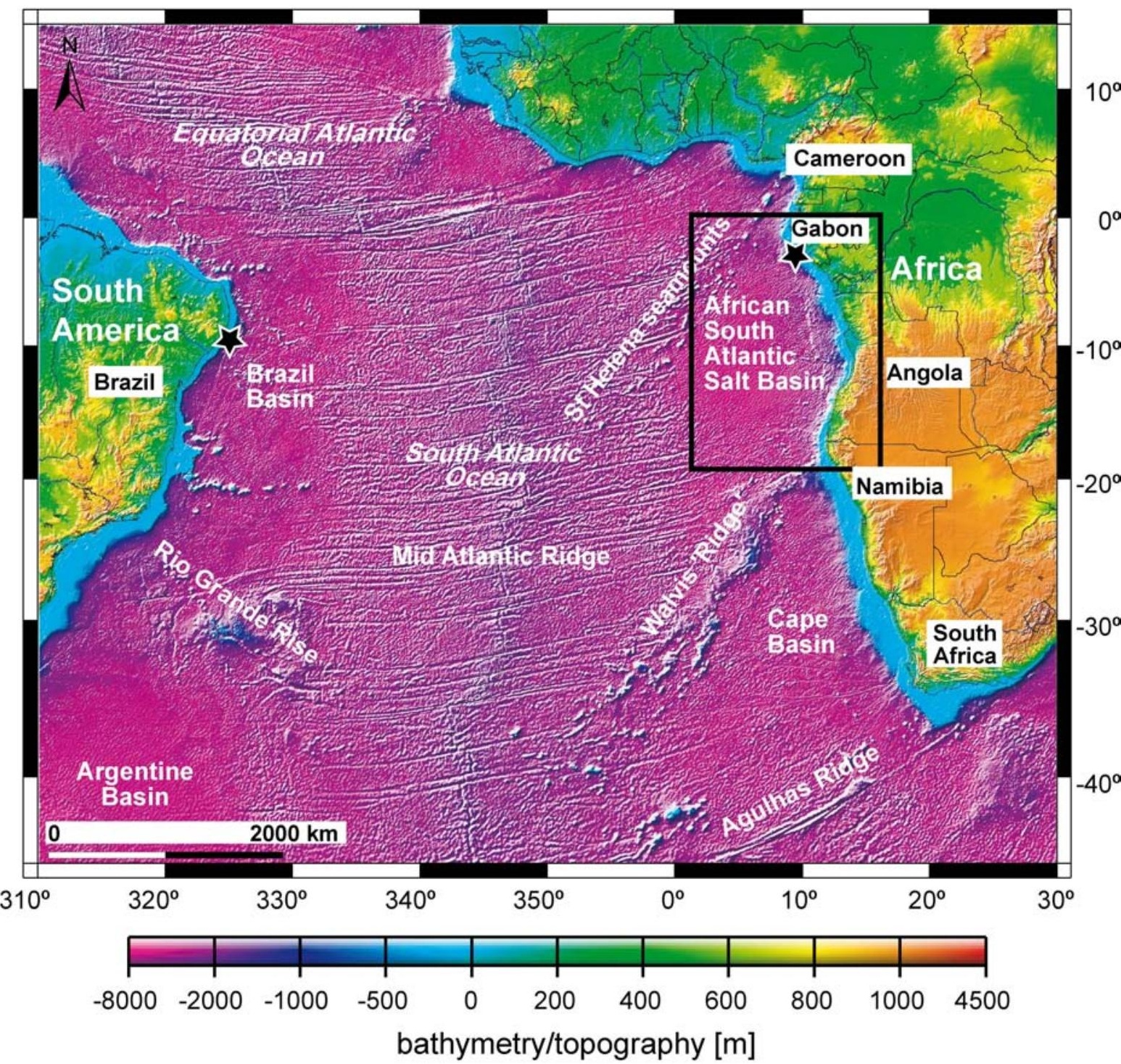




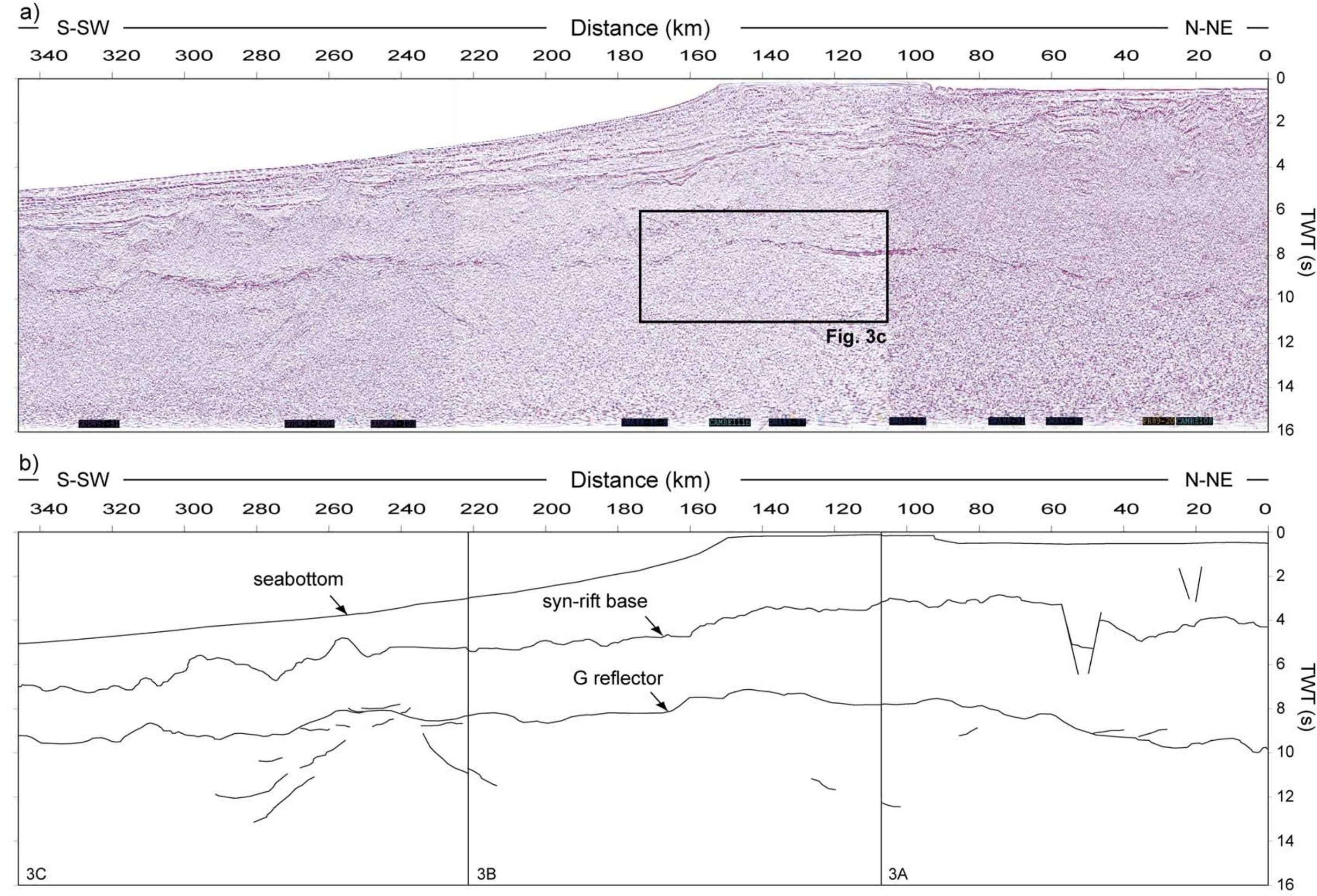




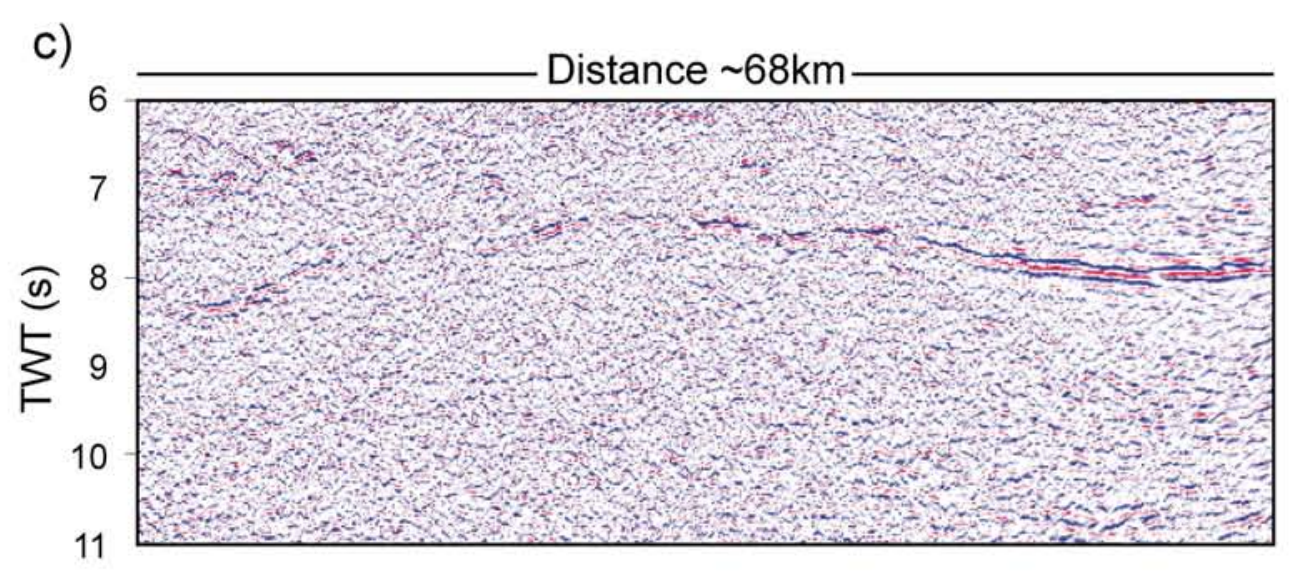



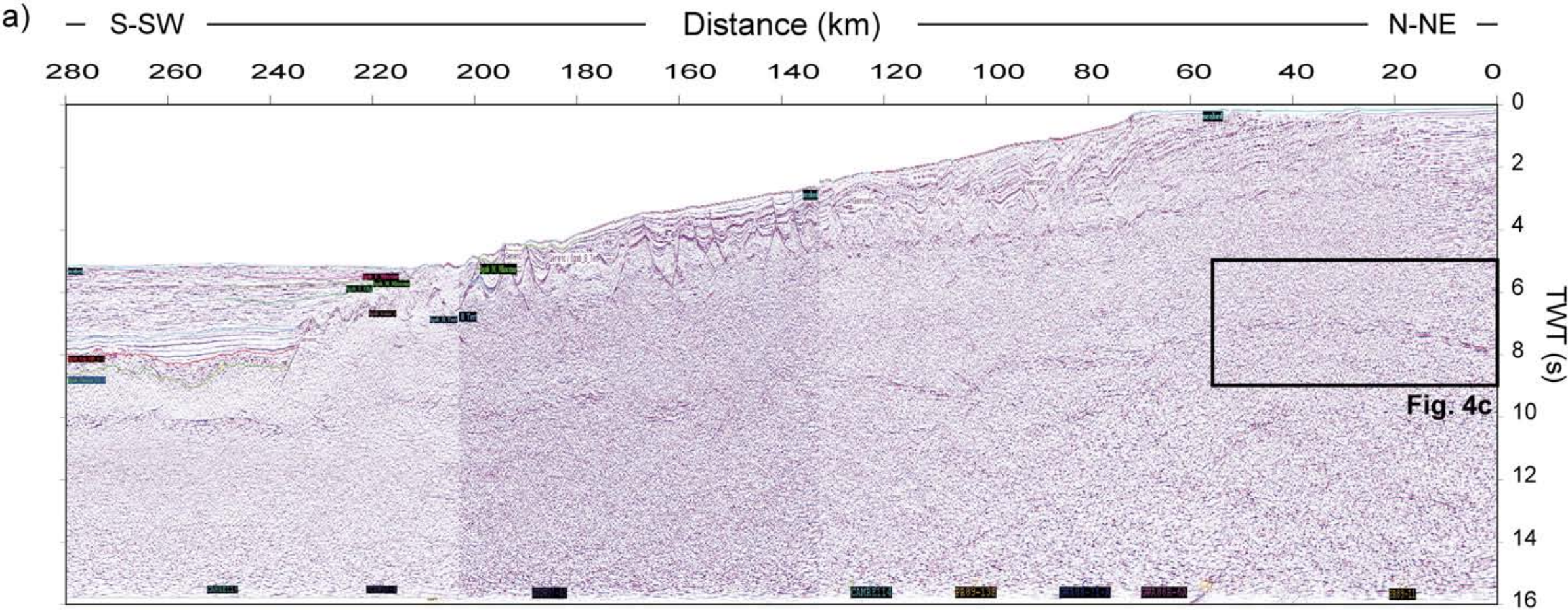

b)

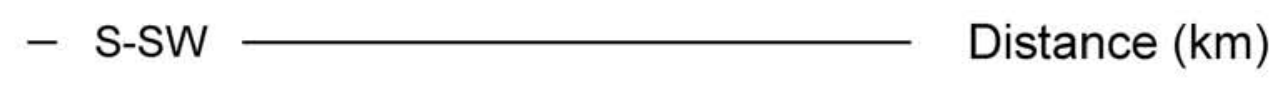

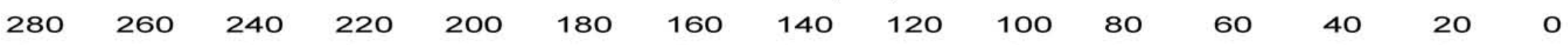

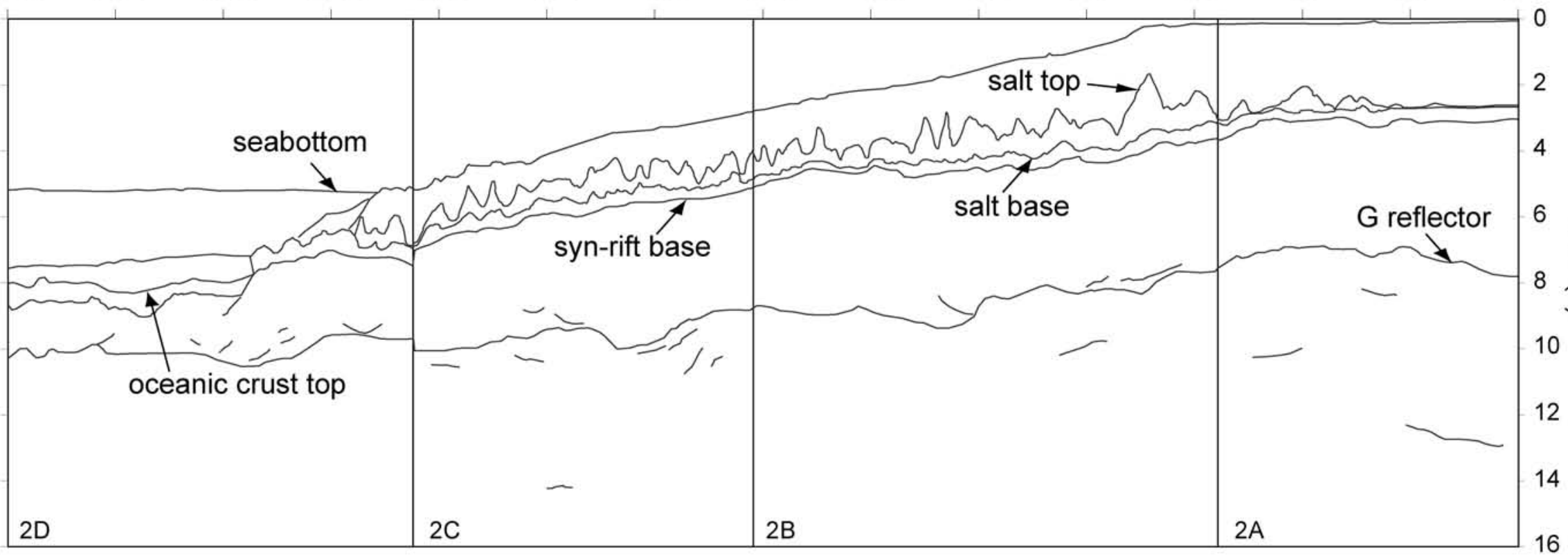


c)

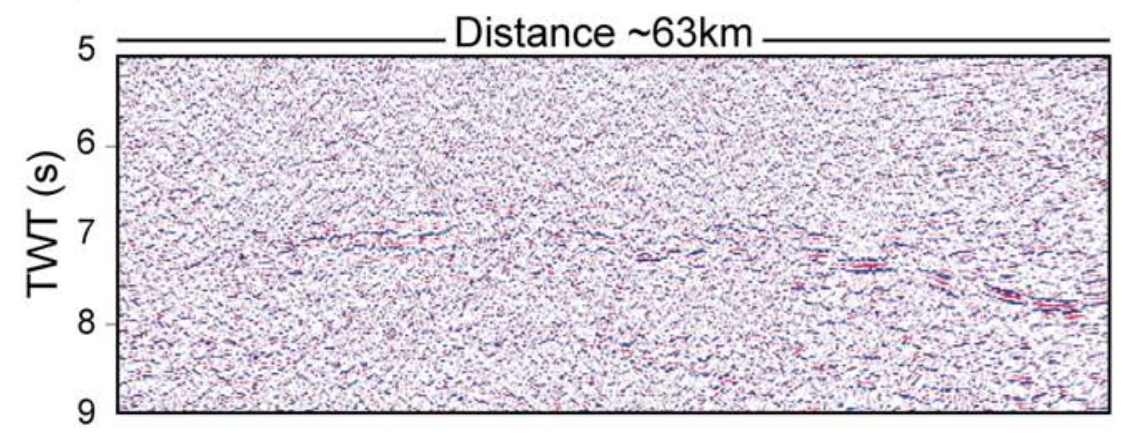


a)

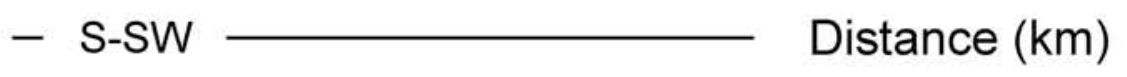

N-NE -

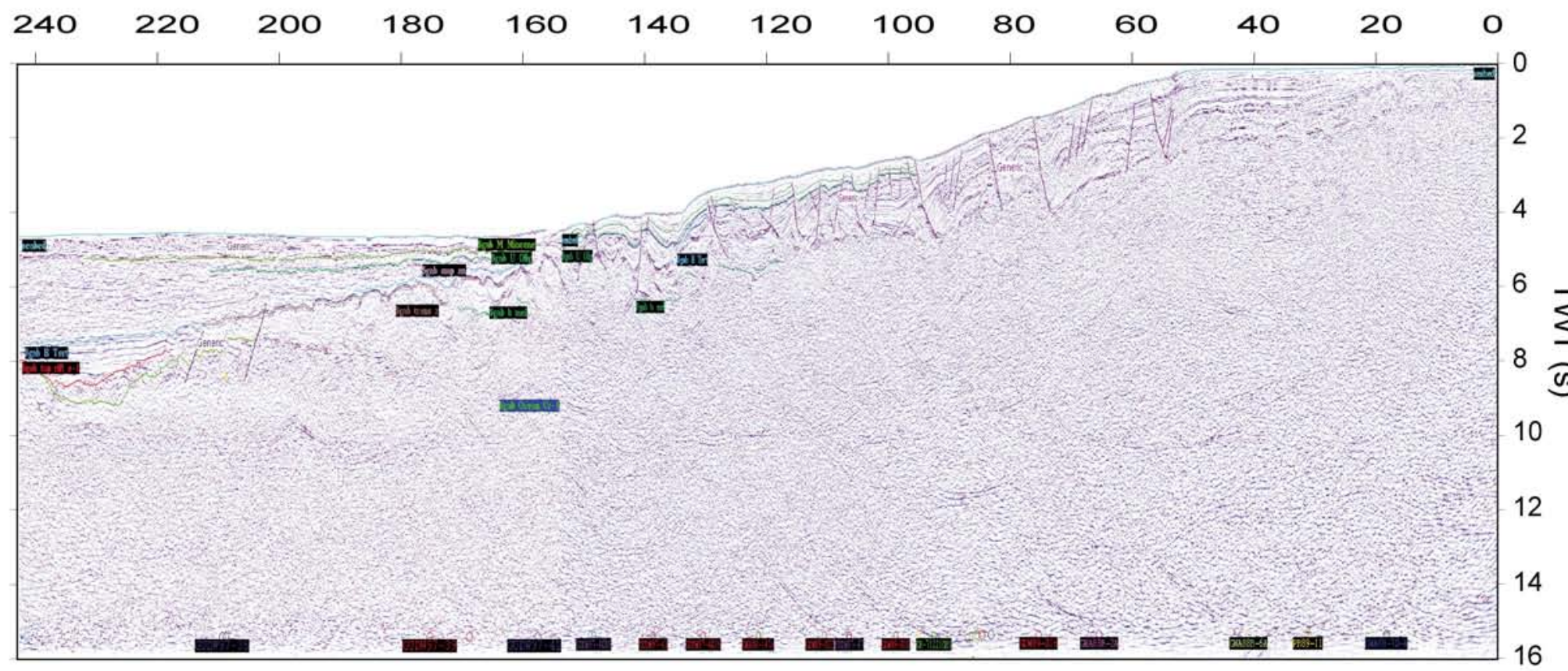

b) - S-sw

Distance $(\mathrm{km})$

N-NE -

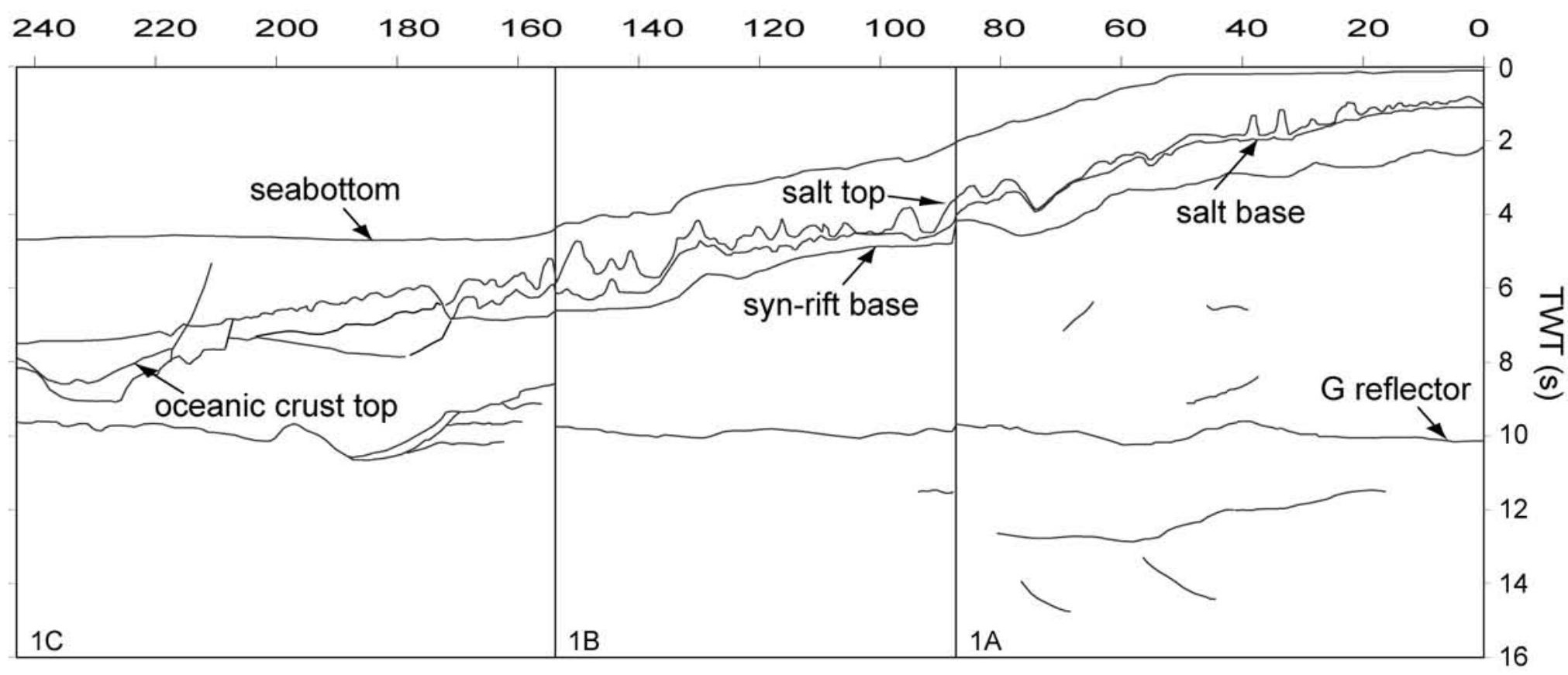



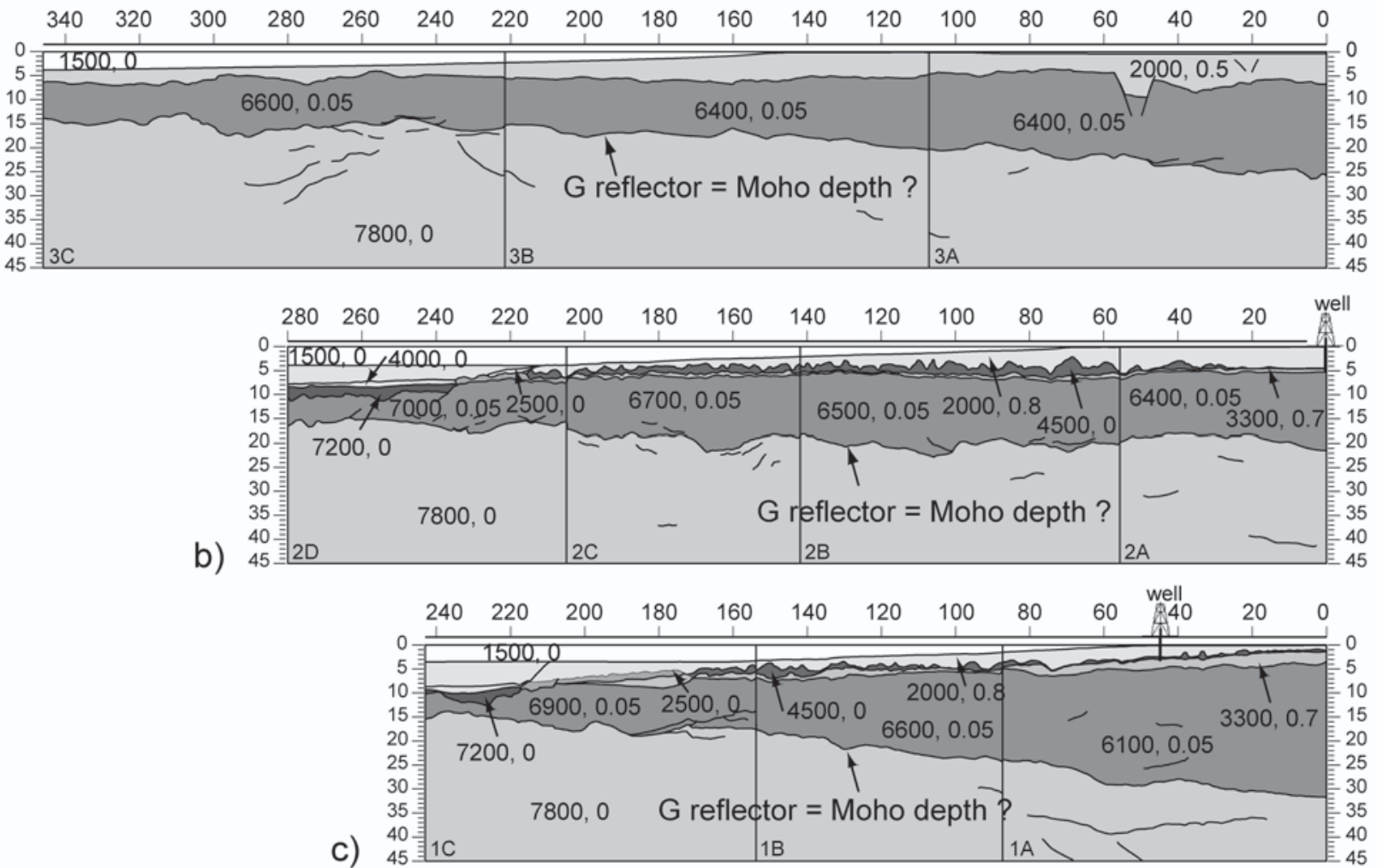

Scale 1:1.3 

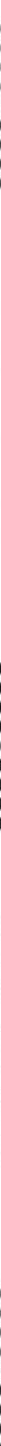

\begin{tabular}{|l}
\hline Observed FAA \\
--- Calculated FAA \\
Error \\
2.7 Density $\left(\mathrm{g} / \mathrm{cm}^{3}\right)$ \\
Vertical exaggeration: 2 \\
\hline
\end{tabular}

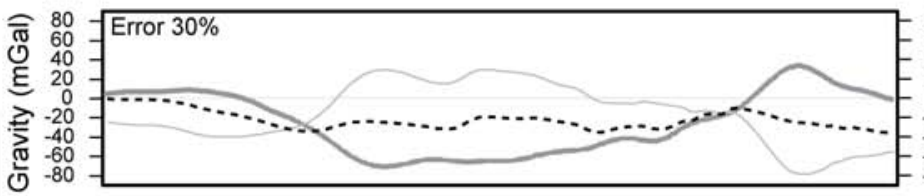


$-\mathrm{S}-\mathrm{SW} \longrightarrow \mathrm{N}-\mathrm{NE}-$
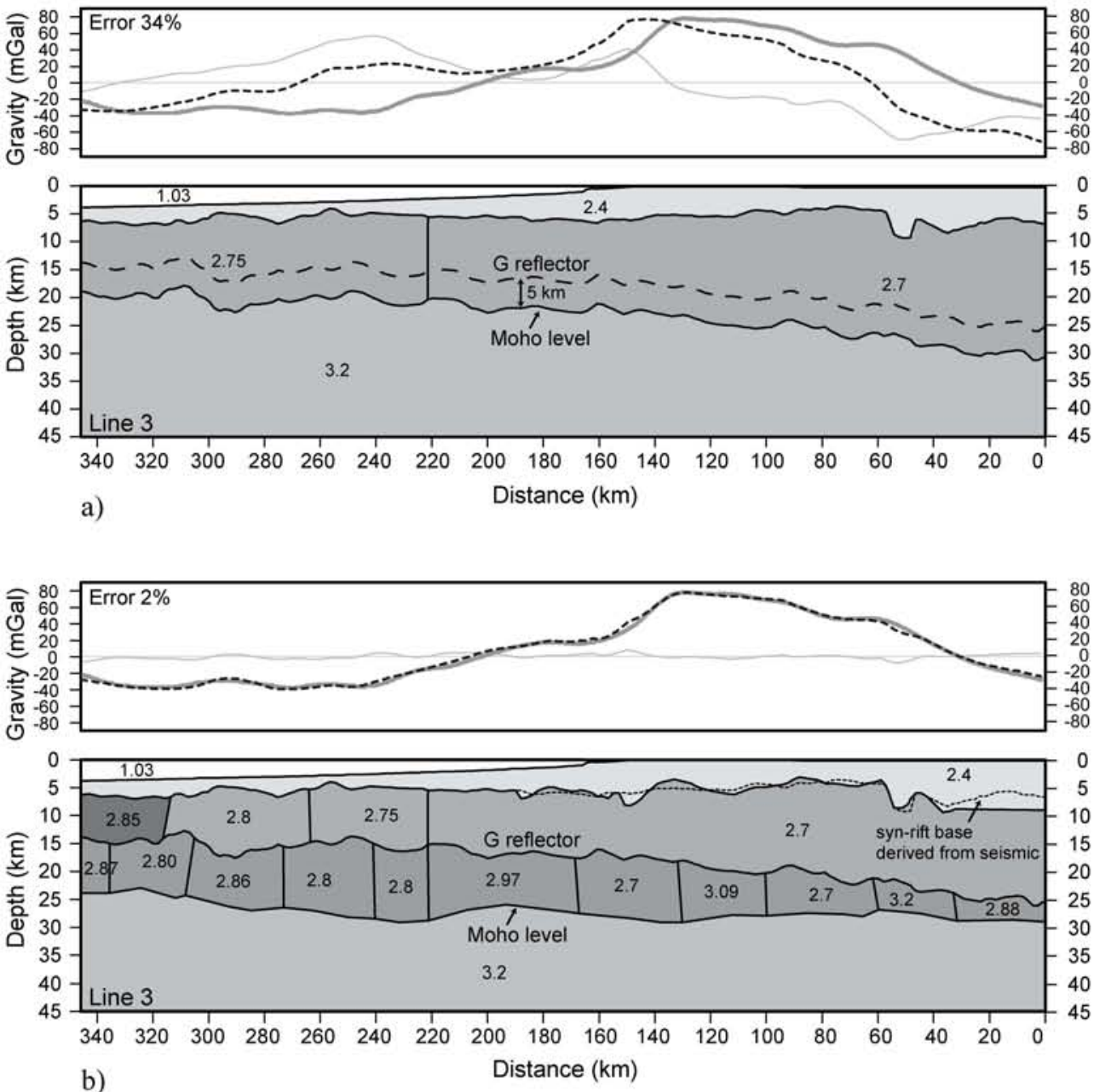

b) Distance $(\mathrm{km})$ 

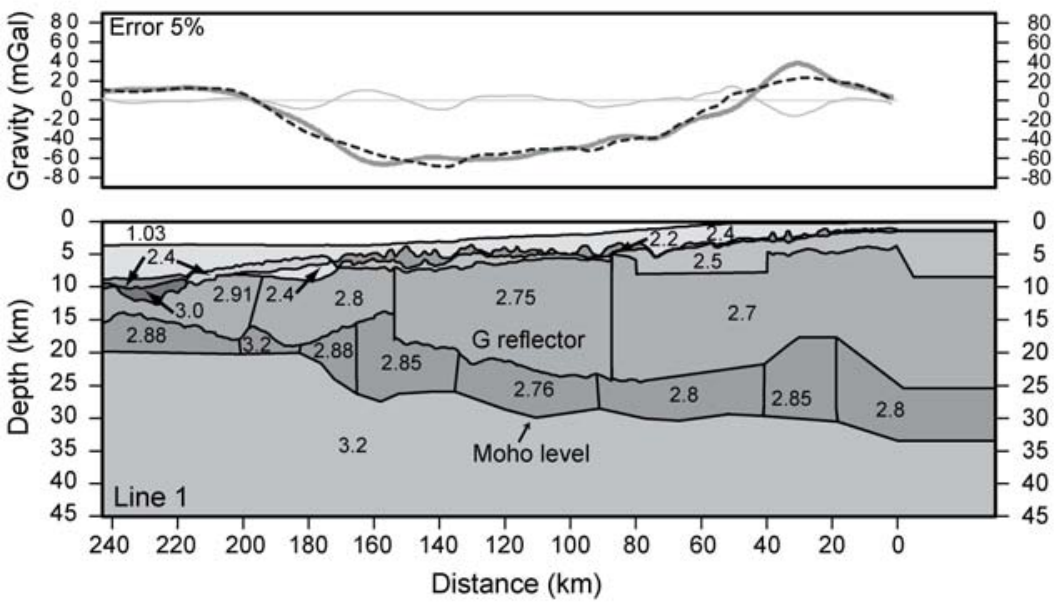
\begin{tabular}{|l|l|l|l|l|l|l|l|l|l|l|l|l|l|l|l|l|}
\hline 3.1 & 3.0 & 2.0 & 2.8 & 2.0 & 2.8 & 3.5 & 4.2 & 4.6 & 6.6 & 4.3 & 5.6 & 3.8 & 4.2 & 6.7 & 8.4 & 8.2 \\
\hline
\end{tabular}

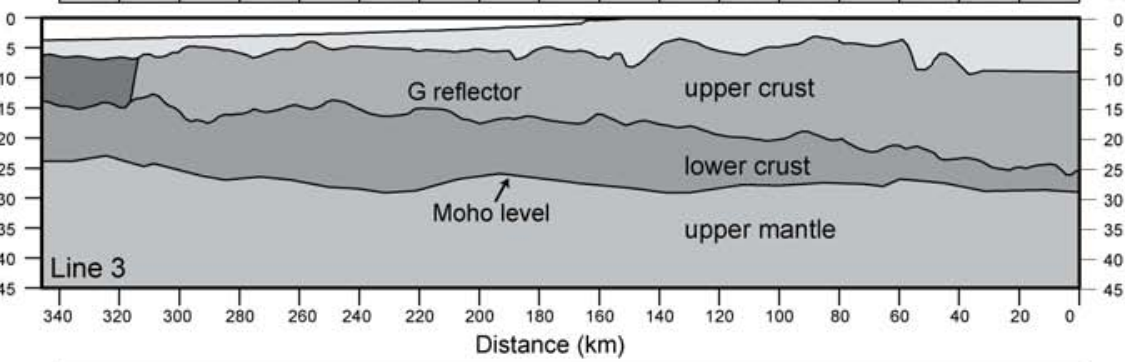

\begin{tabular}{|l|l|l|l|l|l|l|l|l|l|l|l|l|l|l|l|l|}
\hline 17 & 18 & 21 & 21 & 23 & 24 & 22 & 20 & 22 & 22 & 25 & 22 & 24 & 23 & 21 & 20 & 21 \\
\hline
\end{tabular}

\begin{tabular}{|l|l|l|l|l|l|l|l|l|l|l|l|l|l|l|l|l|}
\hline 1.8 & 1.6 & 1.4 & 1.4 & 1.3 & 1.3 & 1.4 & 1.5 & 1.4 & 1.4 & 1.2 & 1.3 & 1.3 & 1.3 & 1.5 & 1.5 & 1.5 \\
\hline
\end{tabular} \begin{tabular}{|l|l|l|l|l|l|l|l|l|l|l|l|l|l|l|l|l|}
\hline 2.0 & 1.9 & 1.6 & 1.6 & 1.5 & 1.4 & 1.6 & 1.7 & 1.6 & 1.6 & 1.4 & 1.5 & 1.4 & 1.5 & 1.7 & 1.7 & 1.7 \\
\hline
\end{tabular}$B_{\max }$

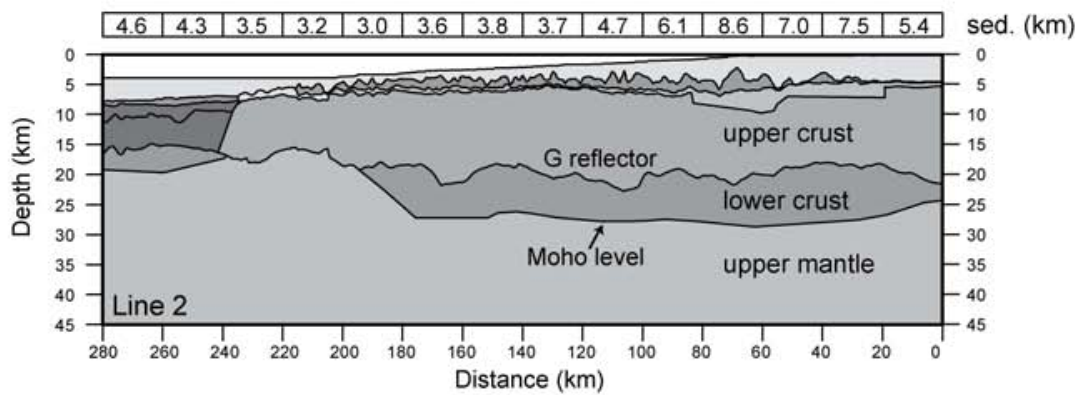

\begin{tabular}{|l|l|l|l|l|l|l|l|l|l|l|l|l|l|l|}
\hline 11 & 11 & 10 & 9 & 15 & 22 & 21 & 22 & 22 & 21 & 19 & 21 & 20 & 20 & crust (km) \\
\hline
\end{tabular}

\begin{tabular}{|l|l|l|l|l|l|l|l|l|l|l|l|l|l|l|}
\hline 2.7 & 2.8 & 3.1 & 3.3 & 2.0 & 1.4 & 1.4 & 1.4 & 1.4 & 1.5 & 1.5 & 1.4 & 1.5 & 1.5 & $B \min$ \\
\hline
\end{tabular} b) \begin{tabular}{l|l|l|l|l|l|l|l|l|l|l|l|l|l|l|l|}
\hline 3.0 & 3.2 & 3.5 & 3.7 & 2.3 & 1.6 & 1.6 & 1.6 & 1.6 & 1.6 & 1.8 & 1.6 & 1.7 & 1.7 \\
\hline
\end{tabular}

\begin{tabular}{|l|l|l|l|l|l|l|l|l|l|l|l|}
\hline 6.2 & 5.2 & 5.0 & 4.1 & 4.1 & 4.0 & 3.6 & 3.9 & 7.0 & 7.6 & 4.5 & 4.0 \\
\hline
\end{tabular}

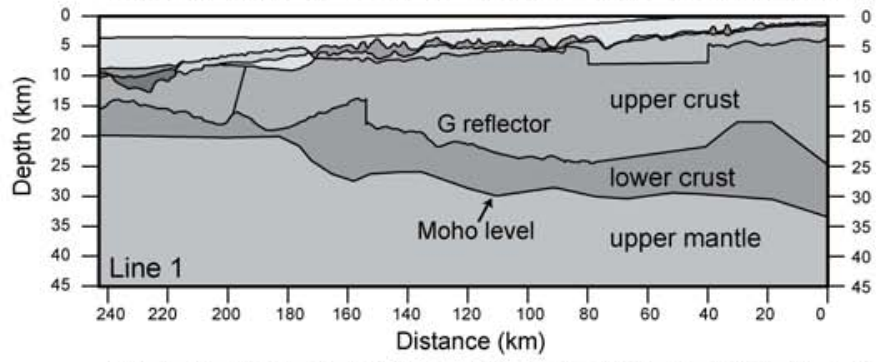

\begin{tabular}{|l|l|l|l|l|l|l|l|l|l|l|l|}
\hline 9 & 11 & 12 & 17 & 19 & 20 & 24 & 23 & 22 & 22 & 25 & 28 \\
\hline
\end{tabular}

\begin{tabular}{l|l|l|l|l|l|l|l|l|l|l|l|l|}
\hline 3.5 & 2.7 & 2.6 & 1.8 & 1.6 & 1.5 & 1.3 & 1.3 & 1.3 & 1.4 & 1.2 & 1.1 & $B_{\min }$ \\
c) & 4.0 & 3.0 & 2.9 & 2.1 & 1.8 & 1.7 & 1.4 & 1.5 & 1.5 & 1.6 & 1.3 & 1.2 \\
\hline
\end{tabular} 